\title{
Geochemistry of the Northern Paraná Continental Flood Basalt (PCFB) Province: implications for regional chemostratigraphy
}

\author{
Fábio Braz Machado*, Eduardo Reis Viana Rocha-Júnior² ${ }^{2}$, Leila Soares Marques³, \\ Antonio José Ranalli Nardy ${ }^{4}$, Larissa Vieira Zezzo ${ }^{4}$, Natasha Sarde Marteleto ${ }^{5}$
}

\begin{abstract}
The Parana Continental Flood Basalt (PCFB) province is one of the largest igneous provinces on Earth, but little is known about the architecture and geochemical characteristics of the lava flows. In this context, a set of borehole samples arranged in an NEE-SWW profile - more than $600 \mathrm{~km}$ long - located in the northern PCFB was used to define its chemostratigraphy. In this region, the outcrops are rare, and the volcanic piles are covered by hundreds of meters of sedimentary rocks from the Bauru Sub-Basin. This study aimed to explore the chemostratigraphic column from northern PCFB to improve the understanding of its internal architecture and to characterize the flood basalt sequences by using the petrography and elemental geochemistry of surface and borehole samples. The results showed the presence of the main four magma types, which were essentially distinguished by their $\mathrm{P}_{2} \mathrm{O}_{5}, \mathrm{TiO}_{2}$ and $\mathrm{Sr}$ concentrations, as well as $\mathrm{Zr} / \mathrm{Y}$ ratios, with excellent chemostratigraphy relations.
\end{abstract}

KEYWORDS: Paraná Continental Flood Basalts; chemostratigraphy; volcanic successions; magma types; geochemistry of boreholes.

\section{INTRODUCTION}

Continental Flood Basalts (CFB) are a type of Large Igneous Province (LIP) that occur as extensive outpourings of juvenile material to the continental crust and represent major, short-lived igneous events on Earth. Despite the wealth of studies on CFB, as well as on the associated geodynamic processes, their genesis remain a controversial subject (Coffin \& Eldholm 1994, 2005, Bryan \& Ernst 2008, Rocha-Júnior et al. 2012, 2013, Ernst 2014, Marques et al. 2017). Usually, CFB provinces are associated with sedimentary basins, having an extremely complex internal architecture, preserving essential information on the onset of flood volcanism, as well as on paleo-environments (Jerram \& Widdowson 2005).
Several chemostratigraphy studies have been carried out on volcanic piles of CFB provinces, such as the Siberian Traps, Karoo, Deccan, and Columbia River, in order to understand the architecture of magmatic dynamics (Ernst 2014).

On the other hand, few chemostratigraphy investigations of lava piles have been accomplished on the Paraná Continental Flood Basalt (PCFB) province. It is noteworthy that, until now, no chemostratigraphy research has been conducted in the northern part of the magmatic province, with all studies concentrated on the central and southern parts of the PCFB province (e.g., Nardy et al. 2002, 2008). This study describes for the first time samples from eight boreholes, as well as some surface samples arranged in an NEE-SWW profile located in the northern PCFB, to better understand the complex internal architecture of lava flows

\footnotetext{
1Departamento de Ciências Ambientais, Instituto de Ciências Ambientais, Universidade Federal de São Paulo - São Paulo (SP), Brazil. E-mail:fabio.machado@unifesp.br ${ }^{2}$ Departamento de Física da Terra e do Meio Ambiente, Instituto de Física, Universidade Federal da Bahia - Salvador (BA),Brazil. E-mail:eduardo.junior@ufba.br 3Instituto de Astronomia, Geofísica e Ciências Atmosféricas, Universidade de São Paulo - São Paulo (SP), Brazil. E-mail: leila.marques@iag.usp.br ${ }^{4}$ Instituto de Geociências e Ciências Exatas, Universidade Estadual Paulista “Júlio de Mesquita Filho” - Rio Claro (SP), Brazil. E-mail: nardy@rc.unesp.br Instituto Geociências, Universidade de São Paulo - São Paulo (SP), Brazil. E-mail: natasha.smarteleto@gmail.com *Corresponding author

Manuscript ID: 20170098. Received on: 07/15/2017. Approved on: 04/02/2018.
} 
and reconstruct the eruptive processes associated with the different magma types.

\section{THE PARANÁ CONTINENTAL FLOOD BASALTS AS A LIP}

The attention to LIPs may be justified by their great relevance on Earth for testing magma generation models, providing temporal marks for stratigraphic correlations of lavas (mainly by geochemistry), paleocontinental reconstructions, and for the importance they have in economic geology (metals, diamonds, rare earth elements - REE, hydrocarbons and aquifers).

Another important aspect is that many LIPs that now lie partially on oceanic and continental lithosphere erupted where rifting led to continental breakup (e.g., Karoo, Ferrar, Central Atlantic Magmatic Province, and Deccan Traps), which may indicate that the locations of melting anomalies are controlled by stress (Anderson 2002), and consequently controlled by plate tectonics. Therefore, the PCFB volcanism agrees with this LIP criterion, since this magmatism took place approximately $10 \mathrm{Ma}$ before the South Atlantic Ocean opening.

The term "Large Igneous Province" was initially proposed by Coffin \& Eldholm (1991, 1992, 1993a, 1993b, $1994)$ to identify a variety of provinces composed by mafic igneous rocks that could reach $>0.1 \mathrm{Mkm}^{2}$. These provinces are found in oceanic and continental areas and include both volcanic and associated intrusive rocks, isolated dyke swarms, sills and other forms of intrusions. Although many LIPs are restricted to the Cenozoic and Mesozoic (Coffin \& Eldholm 2005), such as a large number of continental basaltic provinces (e.g., Paraná, Karoo, Afro-Arabia), rift volcanism (e.g., India-Western Australia, Bushveld), oceanic plateaux (e.g., Ontong Java, Shatsky Rise) and oceanic basaltic provinces (e.g., Nauru Basin, East Mariana), there are others with ages varying from the Archaean to Paleozoic (Ernst \& Buchan 2001, 2003).

Studies (e.g., Sheth 2007, Bryan \& Ernst 2008, Ernst 2014) have collected different types information on these provinces, such as the lithology diversity (presence of rare acid volcanic at the ending of the volcanism), geodynamic characteristics, origin (related or not with mantle plumes) and duration of the main phase of magmatism $(-1-5 \mathrm{Ma})$, among others.

It is noteworthy that most of the LIPs are composed of $\mathrm{SiO}_{2}<56$ wt.\% rocks, represented by phenocrysts-poor tholeiitic basalts and basaltic andesites. However, a significant geochemical variation in the stratigraphy of flows in the most voluminous LIPs (CFB, Oceanic Flood Basalt — OFB and
Silicic LIP — SLIP) is notable (Hooper 1997). Bryan and Ernst (2008) considered most of them, if not all, characterized by products with a bimodal magmatic activity with $\mathrm{SiO}_{2}$ mostly clustered between 45-55 wt.\% and 65-75 wt.\% (e.g., 31-22 Ma Afar-Arabian; 62-53 Ma NAIP, 138-127 Ma Paraná, 190-178 Ma Karoo). Acidic terms are always present at the end of the volcanic event, being usually less expressive (e.g., Paraná with $2.5 \%$ of acidic rocks; Kirstein et al. 2000; Lustrino et al. 2005, 2010, Nardy et al. 2008).

Stratigraphy and correlation of LIP lavas, more precisely of CFB type, have demonstrated strong similarities (MacDougall 1988, Coffin \& Eldholm 1994, Jerran \& Widdowson 2005, Bryan \& Ernst, 2008, Machado et al. 2014, 2015). Basic lava flows with a total thickness of several kilometers have shown intercalation with sediments in almost all volcanic sequences, and the geochemical stratigraphy is marked mainly by variation of $\mathrm{TiO}_{2}$ and $\mathrm{P}_{2} \mathrm{O}_{5}$.

Geochemical stratigraphy has been used in classical models (e.g., Deccan, Paraná, Columbia River) for correlation of flows, mapping and temporal relation, as well as for recognizing formations, members and subgroups (Subbarao et al. 1988, Beane et al. 1986, Mahoney et al. 2000, Nardy et al. 2008, Riedel et al. 2013, and references therein).

As the sixth largest Meso-Cenozoic LIP on Earth, the PCFB (Fig. 1) and its extension in the African Plate (known as Etendeka) are preceded by Madagascar $\left(1.6 \mathrm{Mkm}^{2}\right.$ — Ernst \& Buchan 2001), Deccan (1.8 $\mathrm{Mkm}^{2}$ - Subbarao et al. 1988), Afar (2 $\mathrm{Mkm}^{2}$ - Avini et al. 2012), Siberian Traps

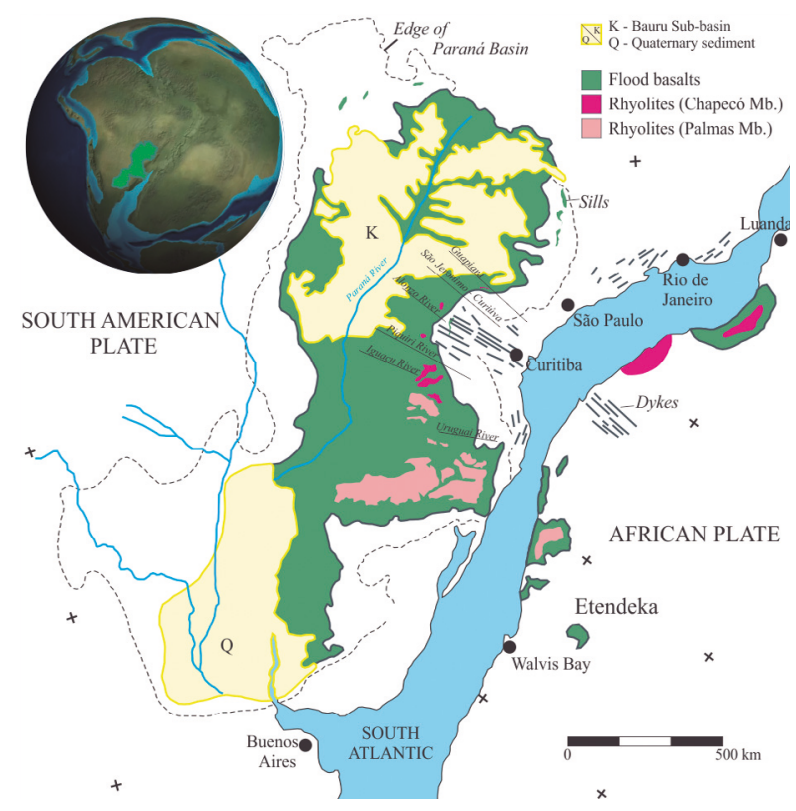

Figure 1. Schematic representation of the Paraná Continental Flood Basalts (Bellieni et al. 1986, Nardy et al. 2008) and their continuation in the African Plate (Etendeka) during Rifting Subphase II of Gondwana (Almeida et al. 2012). 
(7 $\mathrm{Mkm}^{2}$ - Ivanov et al. 2013) and CAMP (10 $\mathrm{Mkm}^{2}$ Bertrand et al. 2014). The area occupies $75 \%$ of the entire Paraná Basin and the estimated volume is $0.8 \mathrm{Mkm}^{3}$, but, according to Courtillot \& Renne (2003), the original volume could have been $>2.3 \mathrm{Mkm}^{3}$. In fact, post-Cretaceous denudation (Quintas et al. 1999, Franco-Magalhães et al. 2013) was deeper in the northern part than in the southern part of the PCFB. The uplift of marginal areas led to the occurrence of a sedimentary unit (Bauru Sub-Basin; Basilici et al. 2012) superposed to the volcanism. This situation considerably reduces the outcrops of basaltic rocks in the northern portion when compared to the southern one.

On the other hand, in the case of Deccan, there are 10 volcanic formations grouped into 3 subgroups, occupying $1.8 \mathrm{Mkm}^{2}$ and accounting for more than $1 \mathrm{Mkm}^{3}$ of lava (Beane et al. 1986, Mahoney et al. 2000). These formations are divided into more than 20 members that are separated by mineralogy, crystal size, and mainly by geochemistry (concentrations of $\mathrm{SiO}_{2}, \mathrm{~K}_{2} \mathrm{O}, \mathrm{MgO}, \mathrm{TiO}_{2}, \mathrm{P}_{2} \mathrm{O}_{5}, \mathrm{Ba}, \mathrm{Sr}, \mathrm{Zr}$ and $\mathrm{Sr}$, as well as ${ }^{87} \mathrm{Sr} /{ }^{86} \mathrm{Sr}$ isotope compositions). It should be noted that, according to Subbarao et al. (1988), some geological formations can exceed $>300 \mathrm{~km}$ of extension.

Similar to Deccan, Columbia River is divided in 5 formations and identified by geochemistry (Faure 2001, Camp \& Hanan, 2008, Riedel et al. 2013) but also by magnetic polarity patterns. They spread over an area of $\sim 0.24 \mathrm{Mkm}^{2}$ with an estimated volume of about $0.3 \mathrm{Mkm}^{3}$, while flows are tabular and extend over for $>600 \mathrm{~km}$.

The PCFB is much older than the Deccan (65 MaChenet et al. 2008) and Columbia River (17 Ma - Glen $\&$ Ponce 2002). The age of the volcanism ranges from 132.8 to $134.9 \mathrm{Ma}$ in the northern part, and 132.9 to 135.9 in the southern area (Renne et al. 1992, 1996, Ernesto et al. 1999, Thiede \& Vasconcelos 2010, Janasi et al. 2011).

Systematic geochemical studies of PCFB were initially conducted by Bellieni et al. (1983, 1984), Mantovani et al. (1985, 1988), Piccirillo et al. (1988) and Peate et al. (1988).
They revealed the existence of two chemically distinct rock groups (and sub-provinces) based on the concentration of $\mathrm{TiO}_{2}$ that were called high titanium $\left(\mathrm{HTi} ; \mathrm{TiO}_{2} \geq 2\right.$ wt.\%) and low titanium $\left(\mathrm{LTi}, \mathrm{TiO}_{2}<2 \mathrm{wt} . \%\right)$ rocks.

Compared to uncontaminated LTi rocks, the HTi ones are enriched in $\mathrm{Ba}, \mathrm{K}_{2} \mathrm{O}, \mathrm{U}, \mathrm{Sr}, \mathrm{La}, \mathrm{Ce}, \mathrm{Ta}, \mathrm{P}_{2} \mathrm{O}_{5}$, Hf and $\mathrm{Zr}$. In general, those of the HTi group are located in the northern PCFB, above the Piquiri River Lineament, while the LTi appears in the southern part, below the Uruguay River Lineament (Fig. 1).

In the southern part of the province, where the LTi rocks strongly prevail, the occurrence of $\mathrm{HTi}$ was identified, corresponding to only $7 \%$ of the basic igneous activity (Piccirillo et al. 1988, Marques et al. 1989, Peate et al. 1992). According to these references, scarce LTi basalts were emplaced in the HTi sub-province (especially in the northwest region), representing $6 \%$ of the basic rocks of the Paraná Basin. However, there are significant geochemical differences between the LTi basalts occurring in the northern (Ribeira type) and southern (Esmeralda and Gramado types) sub-provinces, as well as between the HTi rocks in these two regions, with Pitanga and Paranapanema occurring in northern PCFB and Urubici in the southern. After a detailed study of the rocks that outcrop at the extreme west of the province, Machado et al. (2009) proposed a new compositional variation for the Ribeira magma type.

In the African counterpart (Fig. 1; west of the African continent), basaltic rocks are equivalent to Gramado (Namibia) and Urubici (Angola), denoted as Tafelberg and Khumib, respectively (e.g., Marsh et al. 2001, Ewart et al. 2004). The differences between such magma types were mainly based on contents of $\mathrm{TiO}_{2}$ and incompatible trace elements ( $\mathrm{Sr}, \mathrm{Y}$ and $\mathrm{Zr}$ ), whose main geochemical characteristics are reported in Tab. 1.

As already mentioned, the distribution of these magma types in the PCFB is not random, but there seems to be a pattern of occurrence. An attempt to define a stratigraphy

Table 1. Distinctive geochemical compositions of basic rocks of the so-called Serra Geral Formation within the Paraná sedimentary basin according to Piccirillo et al. (1988), Marques et al. (1989) and Peate et al. (1992). Ribeira magma type data are from Machado et al. (2009).

\begin{tabular}{|c|c|c|c|c|c|}
\hline Group & Magma type & $\mathrm{TiO}_{2}$ (wt.\%) & $\mathrm{Sr}(\mathrm{mg} / \mathrm{g})$ & $\mathrm{Ti} / \mathrm{Y}$ & $\mathrm{Zr} / \mathrm{Y}$ \\
\hline \multirow{3}{*}{$\mathrm{HTi}$} & Urubici & $>3.3$ & $>550$ & $>500$ & $>6.5$ \\
\hline & Pitanga & $>2.9$ & $>350$ & $>350$ & $>5.5$ \\
\hline & Paranapanema & $1.7-3.2$ & $200-450$ & $>330$ & $4-7$ \\
\hline \multirow{3}{*}{$\mathrm{LTi}$} & Gramado & $0.75-1.9$ & $140-400$ & $<300$ & $3.5-6.5$ \\
\hline & Esmeralda & $1.1-2.3$ & $<250$ & $<330$ & $2-5$ \\
\hline & Ribeira & $1.6-2.4$ & $246-286$ & $500-700$ & $3.5-5.4$ \\
\hline
\end{tabular}


for these magma types was accomplished by Turner et al. (1994) and Stewart et al. (1996). Through drilling, associated with geochemical data, it was verified that in the southern PCFB the Esmeralda basalts cover the Urubici and Gramado ones, whereas in the northern part the Paranapanema flows overlap the Pitanga lithotypes.

However, the distribution and stratigraphy of northern $\mathrm{HTi}$ magma types were contested by Machado et al. (2007, 2014, 2015), who reported the presence of some Urubici basalts in the extreme northeast of the province. These basic rocks, until then only found in southern PCFB, are present in flows and nearby sills in that region. Some Urubici dykes also intrude Archean basement rocks (Southern Espinhaço) located at the border of the São Francisco Craton (Marques et al. 2016).

\section{LOCATION AND GEOLOGICAL ASPECTS}

The boreholes are located at the center-northern PCFB in the Paraná Basin (Fig. 2). The maximum reach depths exceed 1,100 meters, crossing the complete sequence of basaltic rocks. Four boreholes cut up to 200 meters of sedimentary rocks of the Bauru Sub-Basin, while the other four cross soil, whose layers can be as thick as $40 \mathrm{~m}$ in the investigated region.

The eight boreholes are aligned in a roughly ENE-WSW direction and cover a distance of $671 \mathrm{~km}$. Surface samples were collected near to FR, B, and IVI boreholes in the western limit of the basin, extending the section to about $877 \mathrm{~km}$.

The oldest geological unit in the boreholes is the Triassic Piramboia Formation (Assine \& Soares 1995). It consists of whitish, yellowish and reddish, medium- to very fine-grained sandstones with sub-angular and sub-rounded grains. There are also intercalations of thin layers of argillites and siltstones.

The Botucatu Formation (Early Jurassic-Cretaceous) is discordant and overlaps the previous unit (Scherer 2000). It is composed almost exclusively of medium to fine granules in sandstones, with good grain selection and high sphericity.

The PCFB province, which is named Serra Geral Formation in the stratigraphy of the Paraná Basin, lies on the top of the Botucatu Formation in concordant contact. Borehole data show that the thickness of the magmatic pile ranges from $80 \mathrm{~m}$ (ALT borehole) to nearly 1,020 m (IVI borehole).

Sometimes, upper and lower parts of the flows are marked by a few centimeters thick vesicular layers. Other boreholes (e.g., FR and GUA) show whole vesiculated flows as thick as $70-80 \mathrm{~m}$.

It is worth mentioning the presence of flow intercalations with sandstones of the Botucatu Formation as thick as $14 \mathrm{~m}, 13 \mathrm{~m}$ and $22 \mathrm{~m}$ in IVI (at $-350 \mathrm{~m}$ below sea level),
PAI (at $470 \mathrm{~m}$ above sea level) and ALT (at $871 \mathrm{~m}$ above sea level) boreholes, respectively.

Also, isolated sills were recognized between lava flows, with thicknesses similar to those of the sheet flows, despite being massive. They were identified in the FR (at $160 \mathrm{~m}$ ) and B (at $210 \mathrm{~m}$ ) boreholes. Sills were identified by their distinctive concentrations of minor and trace elements, as well as by their cross-cut relationships with overlain and underlain flows. As such, a single, massive (14 m-thick) sill occurs in the PAI borehole (at level $236 \mathrm{~m}$ ) intruding sandstones of Piramboia Formation.

\section{MATERIAL AND METHODS}

The boreholes were sampled at $2 \mathrm{~m}$ intervals. Each sample, constituted by a set of rock chips, is representative of the respective entire interval (Fig. 3).

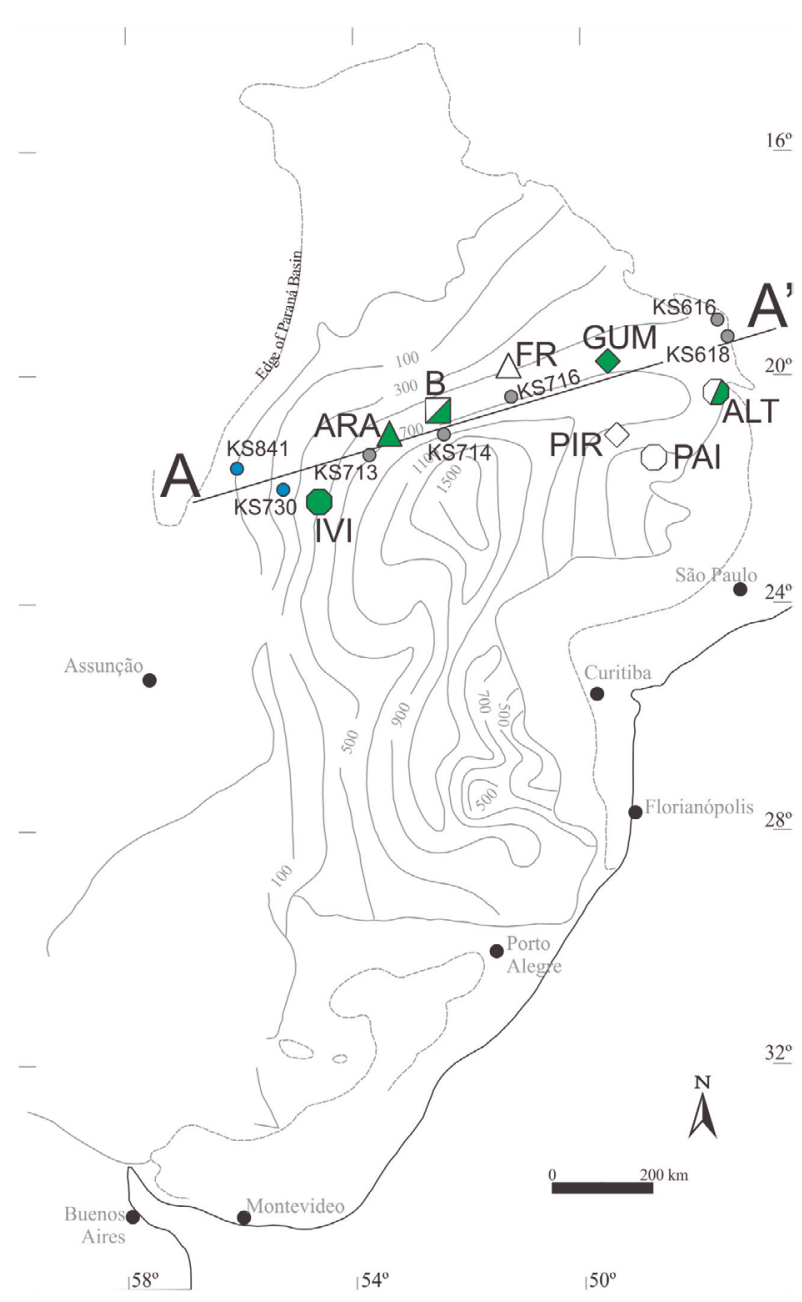

Figure 2. Isopach map of PCFB in Paraná Basin, with contours at $200 \mathrm{~m}$ intervals (Zalán et al. 1987). Symbols mark the location of the studied boreholes and surface samples (KS) and will be used hereafter. 
The samples were placed in beakers, washed in an ultrasonic bath with water and dried in a small fume hood within sieves. After drying, the least altered, massive chips were selected, resulting in nearly 300 samples of basalts. There was also the concern to maintain regular sampling intervals to represent the largest possible number of flows, which were primarily identified by their both upper and lower vesicular limits.

Major and trace elements were obtained by X-Ray fluorescence spectrometry in the Geosciences and Exact Sciences Institute of Universidade Estadual Paulista. Calibration parameters, equipment readings and analytical errors $(<1 \%$ for major elements, and $<5 \%$ for the trace elements) are available in Nardy et al. (1997) and Machado (2010).

Samples with a loss on ignition (LOI) $>2 \mathrm{wt}$ \% or that presented some anomalous concentration for any of the elements were discarded. To make the dataset internally consistent, the major elements were normalized to $100 \%$ on a volatile-free basis.

A subset of 13 samples was selected for REE and other trace element analysis by Inductively Coupled Plasma Mass Spectrometry (ICP-MS), at the Geosciences Institute of Universidade de São Paulo. The analytical error is $<5 \%$ and the methodological procedure adopted can be checked at Navarro et al. (2008). Also, a set of 7 surface samples was also selected to complete the NNESWW stratigraphic profile shown in Fig. 2 as A-A '.

All data of the analyzed samples (major and trace elements) can be accessed in the Supplementary Table A1.

\section{PETROGRAPHIC ASPECTS}

Selected chips from the eight boreholes were immersed in epoxy-type resin for the assembly and preparation of thin sections. After the resin was dried, the samples were cut and properly wiped down.

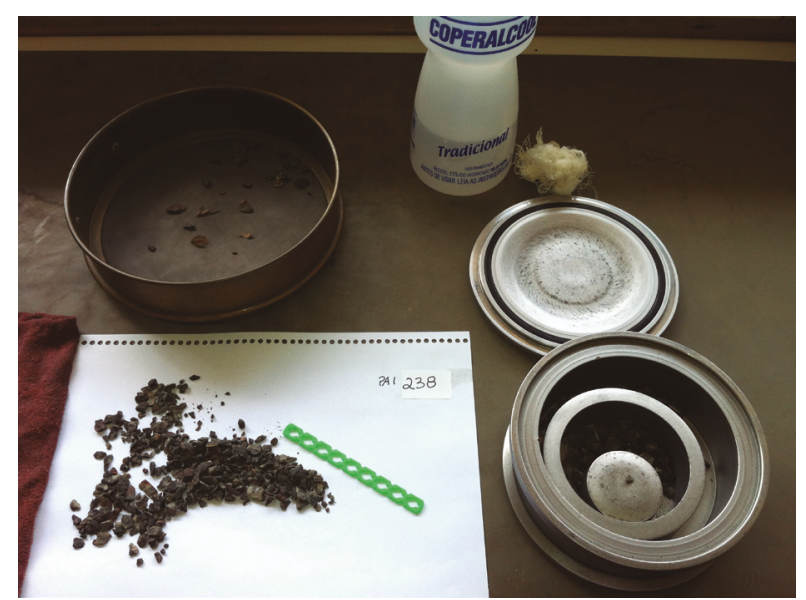

Figure 3. Sample chips selection of PAI 238 for geochemical analysis.
The rocks are characterized by the presence of five essential mineral phases: calcic (augite) and rarely calcium-poor (pigeonite) clinopyroxenes, plagioclase, opaque minerals (probably magnetite and ilmenite) and olivine. Plagioclase is the predominant mineralogical component, reaching up to $50 \%$ of the rock volume. It occurs as microphenocrysts and in the rock matrix, with grain sizes $<0.2 \mathrm{~mm}$. Microphenocrysts are subhedral, lath-shaped, with Carlsbad and Albite-Carlsbad twinning. They are sometimes zoned or show corroded edges by the matrix. Occasionally the plagioclase crystals are saussuritized.

Clinopyroxenes constitute up to $45 \%$ of the rock volume (maximum of $2 \%$ are pigeonite). They are mostly anhedral to subhedral, occurring in the matrix with a granular habit or as inclusions in plagioclase.

Olivine is entirely or partially altered to a reddish brown mineral, probably iddingsite. It occurs in the matrix surrounded by clinopyroxenes. The olivine crystals comprise less than $3 \%$ of the volume of the rocks.

Opaque minerals (probably magnetite and ilmenite) constitute up to $20 \%$ of the total volume. They appear interstitially in the matrix, and as microphenocrysts, often subhedral.

Dark-brown to black glass occurs interstitially in the matrix in variable amounts, but may constitute as much as $60 \%$ of the volume of the rocks.

\section{LITHOGEOCHEMISTRY}

According to the total alkali versus silica (TAS) classification (Le Maitre 2002; Fig. 4), the studied basalts show

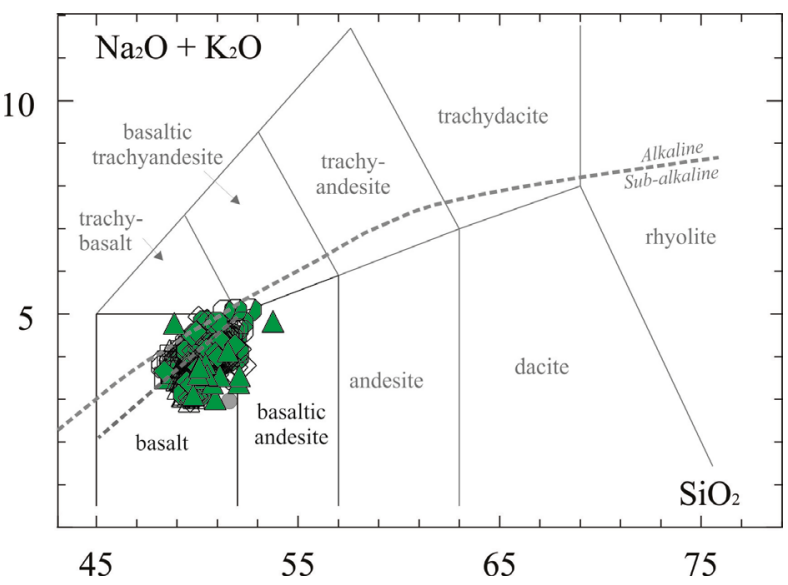

Figure 4. Classification and nomenclature of the analyzed samples, according to the TAS scheme (Le Maitre 2002). The upper dashed line separates alkaline and sub-alkaline fields (from Miyashiro 1978), whereas the lower dashed line shows the dividing line of MacDonald and Katsura (1964) for Hawaiian basalts. Oxides in wt.\% recalculated to $100 \%$ on a volatile-free basis. Symbols as shown in Fig. 2. 
sub-alkaline to transitional affinity. These basalts have $\mathrm{SiO}_{2}$ concentrations varying from 48.2 to $54.4 \mathrm{wt} . \%$, with an average of $50.3 \pm 0.9$ wt. $\%$. Moreover, these rocks have tholeiitic affinity with strong enrichment of $\mathrm{Fe}_{2} \mathrm{O}_{3(\mathrm{t})}$ (12.9317.70 wt.\%) when compared to alkalis $\left(\mathrm{Na}_{2} \mathrm{O}+\mathrm{K}_{2} \mathrm{O}=2.96-\right.$ 5.10 wt.\%) and $\mathrm{MgO}$ (3.21-7.47 wt.\%).

The variations of major and trace elements relative to $\mathrm{MgO}$ are shown in Figs. 5 and 6. The investigated samples define trends for all elements except for $\mathrm{Fe}_{2} \mathrm{O}_{3(\mathrm{t})}$. In general, $\mathrm{SiO}_{2}, \mathrm{TiO}_{2}, \mathrm{Na}_{2} \mathrm{O}, \mathrm{K}_{2} \mathrm{O}$, and $\mathrm{P}_{2} \mathrm{O}_{5}$ increase, whereas $\mathrm{CaO}$ and $\mathrm{Al}_{2} \mathrm{O}_{3}$ decrease with decreasing $\mathrm{MgO}$. Although some scattering is observed, the trends are compatible with fractional crystallization, and form a continuous, evolutionary trend, similar to those presented in previous studies (Bellieni et al. 1984, Piccirillo \& Melfi 1988, Peate et al. 1992, Marques et al. 1999, Rocha-Júnior et al. 2013). Major element variations, for the same $\mathrm{MgO}$ content, are broadly similar for lava flows and intrusive rocks, and they do not vary with the stratigraphic height (for the lava piles) or sampling location.

Five samples from PIR are enriched in $\mathrm{MgO}$ (6.51$7.47 \mathrm{wt} . \%$ ) in comparison to those from the other boreholes located on the NEE side of the profile. These samples occur within a $10 \mathrm{~m}$-thick sequence, close to level $400 \mathrm{~m}$.

The ALT borehole (at the NEE end of profile) presents a sequence of 10 samples located at its bottom, close to level $900 \mathrm{~m}$, corresponding to a thickness of at least 25 meters. The $\mathrm{P}_{2} \mathrm{O}_{5}$ content of these samples is higher than in the other samples (up to $0.81 \mathrm{wt} . \%$ ), and this sequence also appears to include two distinct groups: one with $\mathrm{P}_{2} \mathrm{O}_{5}>$ 0.58 wt. $\%$ and the other with $\mathrm{P}_{2} \mathrm{O}_{5}<0.52$ wt. $\%$. Samples from ALT borehole with 0.73 to $0.81 \mathrm{wt} \%$ of $\mathrm{P}_{2} \mathrm{O}_{5}$ are also enriched in $\mathrm{La}(41-47 \mathrm{ppm}), \mathrm{Ba}(575-657 \mathrm{ppm})$ and $\mathrm{Rb}$ (30-39 ppm).

A group of 13 samples (whole rocks with LOI < 2.0 wt.\%) was selected for REE analysis and other trace elements (Tab. 2). The investigated rocks show positive correlations between compatible trace elements, such as $\mathrm{Ni}$ and $\mathrm{Cr}$ (not shown), and $\mathrm{MgO}$, although the most evolved samples have variable $\mathrm{Ni}$ contents. Incompatible trace elements such as $\mathrm{La}$ (7-52 ppm), Ce (13-115 ppm), Ba (236-660 ppm), Zr (115-306 ppm), Y (23-47 ppm), Nb (10-27 ppm), and $\mathrm{Rb}$ (14-39 ppm) generally increase with the degree of differentiation (MgO; Fig. 6).

In general, the concentrations of these incompatible elements show positive correlations with each other (not shown). It should be noted that the samples from ALT borehole with 0.73 to 0.81 wt. $\%$ of $\mathrm{P}_{2} \mathrm{O}_{5}$ are also enriched in $\mathrm{La}$ (41-47 ppm), Ba (575-657 ppm) and Rb (30-39 ppm).

All 13 samples have similar REE contents, and their patterns display a fractionation of light REE (LREE) to heavy (HREE), as indicated by $(\mathrm{La} / \mathrm{Yb})_{\mathrm{N}}$ ratios ranging from 2.3 to 8.8 (Fig. 7). This behavior is expected from melting of garnet-bearing sources, as also pointed out in previous studies (e.g., Piccirillo \& Melfi 1988). For most of the samples the enrichment in LREE relative to HREE is directly correlated with REE and $\mathrm{SiO}_{2}$ concentrations. The Pitanga (pit) sequences have (La/ $\mathrm{Yb})_{\mathrm{N}}$ ratios ranging from 7.3 to $8.8 ;(\mathrm{La} / \mathrm{Sm})_{\mathrm{N}}$ from 2.3 to 2.6; and $(\mathrm{Sm} / \mathrm{Yb})_{\mathrm{N}}$ from 3.1 to 3.6. Paranapanema (par) flow sequences have less enrichment in LREE to HREE, as indicated by their $(\mathrm{La} / \mathrm{Yb})_{\mathrm{N}}$ ratios $(2.1-$ 2.4). Also, there are no large variations in Eu anomalies (interpolation of the values of normalized $\mathrm{Sm}$ and $\mathrm{Gd})$ in pit $\left(\mathrm{Eu} / \mathrm{Eu}^{*}=0.94-1.01\right)$ and par $\left(\mathrm{Eu} / \mathrm{Eu}^{*}=\right.$ $0.92-0.95)$ sequences.

A normalized multielement diagram for the studied samples is shown in Fig. 8. The patterns of these rocks exhibit significant enrichment in LILE, such as Th, Ba, Rb, and $\mathrm{K}$, relative to some HFSE (such as $\mathrm{Nb}, \mathrm{Zr}$, Ti, and $\mathrm{P}$ ). Compared to the Paranapanema sequences, the Pitanga rocks have slightly enriched patterns, as also shown by RochaJúnior et al. (2013).

As expected, the Urubici samples have a more enriched pattern while those from the Ribeira samples have the most depleted patterns of the set of rocks analyzed. In addition, the incompatible trace element patterns of the analyzed samples reveal distinct negative anomalies for $\mathrm{Nb}$, weak negative anomalies for Th, Sr (except for Urubici), and $\mathrm{P}$, implying the participation of subcontinental lithospheric mantle source (SCLM), as observed for most PCFB (Piccirillo \& Melfi 1988, Hawkesworth et al. 1992, Marques et al. 1999). As observed by Rocha-Júnior et al. (2013) and Marques et al. (2016), these patterns resemble those found in subduction environments (island-arc basalts), as well as in continental crust.

\section{CHEMOSTRATIGRAPHY OF LAVA FLOWS}

The FR borehole was selected as a reference in order to put constraints on the chemostratigraphy of lava flows based on its following characteristics:

- high variation in $\mathrm{P}_{2} \mathrm{O}_{5}, \mathrm{TiO}_{2}$ and $\mathrm{Sr}$ concentrations, as well as in $\mathrm{Zr} / \mathrm{Y}$ ratios, allowing to recognize the occurrence of Pitanga and Paranapanema magma types (Tab. 1);

- large thickness (more than $800 \mathrm{~m}$ ) of basalts;

- large number of flows $(=7)$;

- large amount of samples (103 samples) with low LOI (<1.5 wt.\%). 

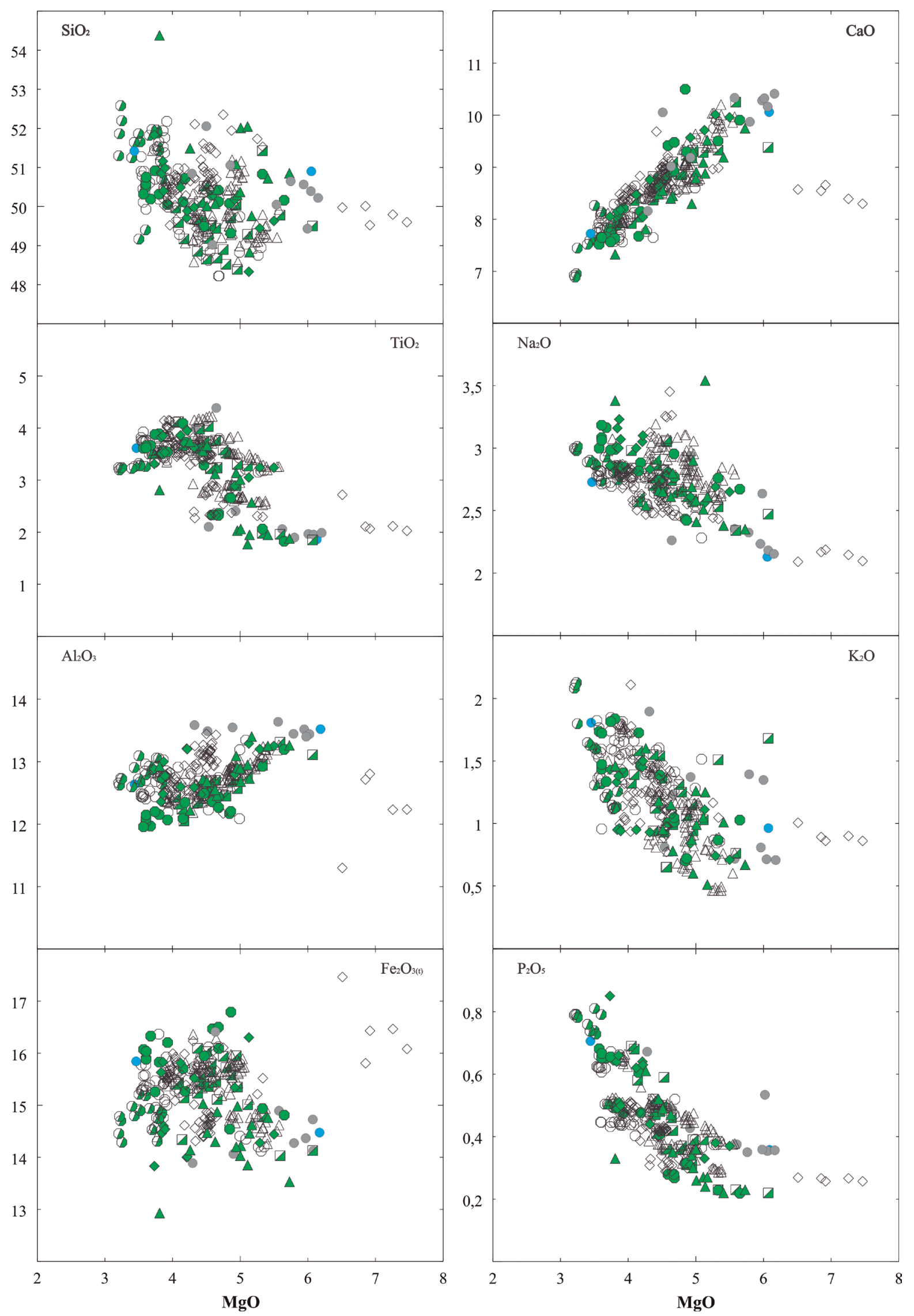

Figure 5. Major element variation versus $\mathrm{MgO}$ content for the investigated basalts. Values in wt.\%. Total iron as $\mathrm{Fe}_{2} \mathrm{O}_{3(\mathrm{t})}$. Symbols as shown in Fig. 2. 

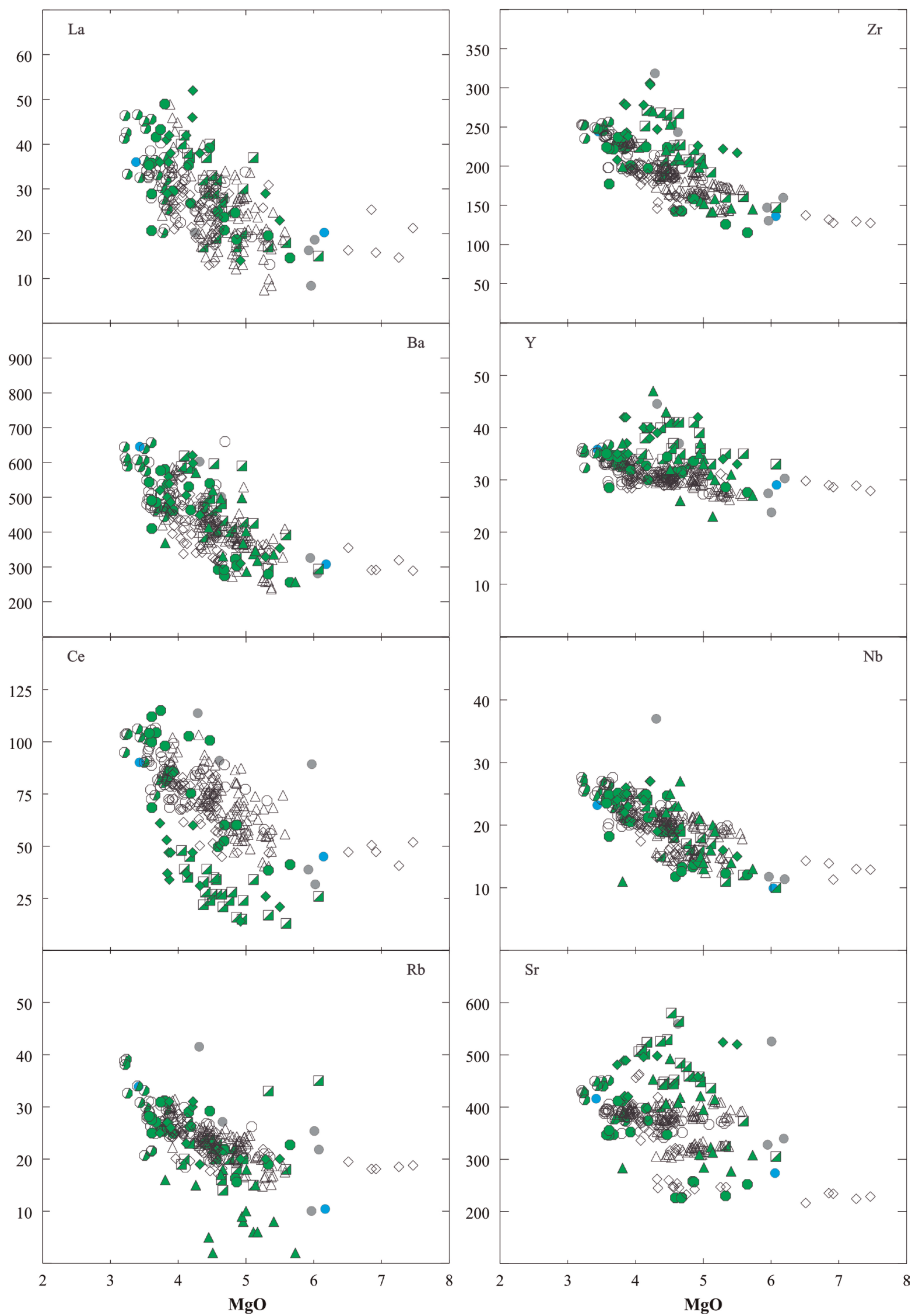

Figure 6. Variation diagrams for trace elements (ppm) against MgO (wt.\%) for the investigated basalts. Symbols as shown in Fig. 2. 
Acronyms were attributed to the FR borehole samples to distinguish the flow successions based on their geochemical characteristics, following the temporal order and the consequent correlation with the other boreholes.
In this correlation, it was possible to assign ranges in concentrations of $\mathrm{TiO}_{2}, \mathrm{MgO}, \mathrm{P}_{2} \mathrm{O}_{5}, \mathrm{Sr}$, and $\mathrm{Zr} / \mathrm{Y}$ ratios for the flows to all eight boreholes shown in Tab. 3, including the surface samples. It is important to note that the

Table 2. Major and trace element data for representative samples of basalts in the study area. Total iron as $\mathrm{Fe}_{2} \mathrm{O}_{3(t)}$. Oxides in wt.\%. Elements in ppm.

\begin{tabular}{|c|c|c|c|c|c|c|c|c|c|c|c|c|c|}
\hline Sample & FR240 & FR54 & FR-148 & FR-282 & GUM123 & KS841 & PAI238 & PAI236 & PAI614 & PIR419 & PIR413 & PIR327 & PAI454 \\
\hline Flow & pit1 & pit3 & par1 & par2 & uru1 & rib1 & pit2 & pit2 & pit1 & pit2 & pit2 & par1 & pit2 \\
\hline $\begin{array}{l}\text { Magma } \\
\text { type }\end{array}$ & pitanga & pitanga & paranapanema & paranapanema & urubici & ribeira & pitanga & pitanga & pitanga & pitanga & pitanga & paranapanema & pitanga \\
\hline $\mathrm{SiO}_{2} \mathrm{wt} . \%$ & 49.62 & 49.92 & 49.26 & 50.58 & 49.89 & 50.91 & 50.54 & 50.37 & 49.79 & 50.48 & 50.02 & 51.49 & 51.94 \\
\hline $\mathrm{TiO}_{2}$ & 4.18 & 3.26 & 2.59 & 2.81 & 3.95 & 1.83 & 3.64 & 3.61 & 3.73 & 3.67 & 3.82 & 2.71 & 3.44 \\
\hline $\mathrm{Al}_{2} \mathrm{O}_{3}$ & 12.45 & 13.27 & 12.93 & 12.42 & 13.20 & 13.39 & 12.96 & 12.85 & 12.57 & 12.51 & 12.49 & 12.77 & 12.79 \\
\hline $\mathrm{Fe}_{2} \mathrm{O}_{3(\mathrm{t})}$ & 15.90 & 14.62 & 14.93 & 15.99 & 14.01 & 14.16 & 15.77 & 15.58 & 15.92 & 15.54 & 16.23 & 15.56 & 15.40 \\
\hline $\mathrm{MnO}$ & 0.22 & 0.20 & 0.20 & 0.21 & 0.18 & 0.23 & 0.18 & 0.18 & 0.23 & 0.19 & 0.20 & 0.20 & 0.18 \\
\hline $\mathrm{MgO}$ & 4.39 & 5.58 & 5.29 & 4.53 & 4.22 & 6.07 & 3.60 & 3.59 & 4.42 & 3.87 & 4.30 & 4.49 & 3.86 \\
\hline $\mathrm{CaO}$ & 8.44 & 9.97 & 9.96 & 8.58 & 8.04 & 10.08 & 8.03 & 8.08 & 8.65 & 8.32 & 8.64 & 8.52 & 7.65 \\
\hline $\mathrm{Na}_{2} \mathrm{O}$ & 2.89 & 2.79 & 2.60 & 2.72 & 3.10 & 2.17 & 2.81 & 2.82 & 2.72 & 2.76 & 2.79 & 2.55 & 2.86 \\
\hline $\mathrm{K}_{2} \mathrm{O}$ & 1.43 & 0.77 & 0.49 & 1.24 & 1.50 & 0.96 & 1.59 & 1.57 & 1.59 & 1.55 & 1.55 & 1.41 & 1.79 \\
\hline $\mathrm{P}_{2} \mathrm{O}_{5}$ & 0.50 & 0.38 & 0.30 & 0.38 & 0.63 & 0.22 & 0.45 & 0.45 & 0.51 & 0.48 & 0.47 & 0.34 & 0.45 \\
\hline $\mathrm{Ni}$ ppm & 6 & 62 & 58 & 37 & 63 & 54 & 23 & 23 & 33 & 38 & 38 & 45 & 23 \\
\hline $\mathrm{Ba}$ & 431 & 410 & 258 & 399 & 598 & 279 & 484 & 470 & 422 & 498 & 469 & 373 & 507 \\
\hline $\mathrm{Rb}$ & 25 & 18 & 17 & 26 & 31 & 22 & 26 & 26 & 27 & 25 & 24 & 24 & 25 \\
\hline $\mathrm{Sr}$ & 394 & 393 & 325 & 303 & 748 & 276 & 390 & 393 & 342 & 379 & 364 & 260 & 395 \\
\hline $\mathrm{Zr}$ & 194 & 170 & 145 & 172 & 304 & 127 & 199 & 197 & 195 & 192 & 184 & 162 & 228 \\
\hline $\mathrm{Y}$ & 30.4 & 27.0 & 27.8 & 32.9 & 40.0 & 29.1 & 30.6 & 29.3 & 31.6 & 30.7 & 31.1 & 32.1 & 31.4 \\
\hline $\mathrm{Nb}$ & 22 & 18 & 15 & 14 & 27 & 9 & 20 & 20 & 22 & 21 & 22 & 16 & 23 \\
\hline $\mathrm{La}$ & 35.4 & 26.8 & 21.2 & 26.5 & 32.8 & 17.2 & 33.1 & 33.6 & 35.6 & 35.6 & 33.6 & 26.6 & 36.6 \\
\hline $\mathrm{Ce}$ & 77.0 & 59.8 & 47.0 & 58.7 & 75.8 & 37.5 & 73.6 & 74.6 & 77.4 & 77.5 & 74.0 & 57.4 & 80.0 \\
\hline $\operatorname{Pr}$ & 9.95 & 7.84 & 6.30 & 7.76 & - & 4.80 & 9.61 & 9.77 & 9.91 & 9.91 & 9.58 & 7.36 & 10.4 \\
\hline $\mathrm{Nd}$ & 42.0 & 34.0 & 27.7 & 34.4 & 37.7 & 20.6 & 41.4 & 42.3 & 41.9 & 41.9 & 40.8 & 31.6 & 44.9 \\
\hline $\mathrm{Sm}$ & 8.93 & 7.44 & 6.51 & 8.07 & 7.85 & 4.80 & 9.12 & 9.30 & 9.10 & 9.04 & 8.92 & 7.18 & 9.62 \\
\hline $\mathrm{Eu}$ & 2.78 & 2.32 & 2.07 & 2.45 & 2.48 & 1.56 & 2.83 & 2.83 & 2.71 & 2.71 & 2.62 & 2.12 & 2.89 \\
\hline $\mathrm{Gd}$ & 7.95 & 6.40 & 5.79 & 7.44 & 7.34 & 5.25 & 7.75 & 7.83 & 7.96 & 7.89 & 7.77 & 6.69 & 8.42 \\
\hline $\mathrm{Tb}$ & 1.24 & 1.05 & 1.00 & 1.29 & 1.35 & 0.86 & 1.26 & 1.27 & 1.32 & 1.29 & 1.27 & 1.15 & 1.33 \\
\hline Dy & 6.90 & 5.93 & 5.76 & 7.41 & 5.95 & 5.34 & 6.94 & 6.89 & 7.30 & 7.29 & 7.15 & 6.87 & 7.34 \\
\hline Ho & 1.39 & 1.18 & 1.20 & 1.57 & - & 1.08 & 1.35 & 1.37 & 1.48 & 1.45 & 1.44 & 1.50 & 1.47 \\
\hline Er & 3.43 & 2.93 & 3.04 & 3.97 & 2.70 & 3.16 & 3.38 & 3.39 & 3.79 & 3.66 & 3.67 & 3.86 & 3.60 \\
\hline $\mathrm{Tm}$ & 0.49 & 0.44 & 0.46 & 0.60 & - & 0.45 & 0.49 & 0.49 & 0.57 & 0.55 & 0.55 & 0.60 & 0.53 \\
\hline $\mathrm{Yb}$ & 2.94 & 2.50 & 2.72 & 3.60 & 2.24 & 2.90 & 2.89 & 2.84 & 3.29 & 3.22 & 3.18 & 3.67 & 3.05 \\
\hline $\mathrm{Lu}$ & 0.43 & 0.40 & 0.42 & 0.55 & 0.33 & 0.43 & 0.43 & 0.44 & 0.51 & 0.51 & 0.50 & 0.57 & 0.47 \\
\hline
\end{tabular}


distinction among different flows was carried out by using $\mathrm{P}_{2} \mathrm{O}_{5}$, while the discrimination between magma types was mainly based on $\mathrm{Zr} / \mathrm{Y}$ ratios, along with $\mathrm{TiO}_{2}$ and Sr concentrations.

\section{ALT borehole}

The ALT borehole (Fig. 2) top is at an altitude of $945 \mathrm{~m}$ with a $5 \mathrm{~m}$-thick soil cover. The contact between the basalt and the Botucatu Formation sandstone occurs at $-80 \mathrm{~m}$. The total thickness of basaltic flows is therefore $-75 \mathrm{~m}$.

The geochemical data (Fig. 9A) show that pit1 type flows occur up to level $915 \mathrm{~m}$. Pit5 type appears down to the contact with the sandstone, where the final $20 \mathrm{~m}$ correspond to

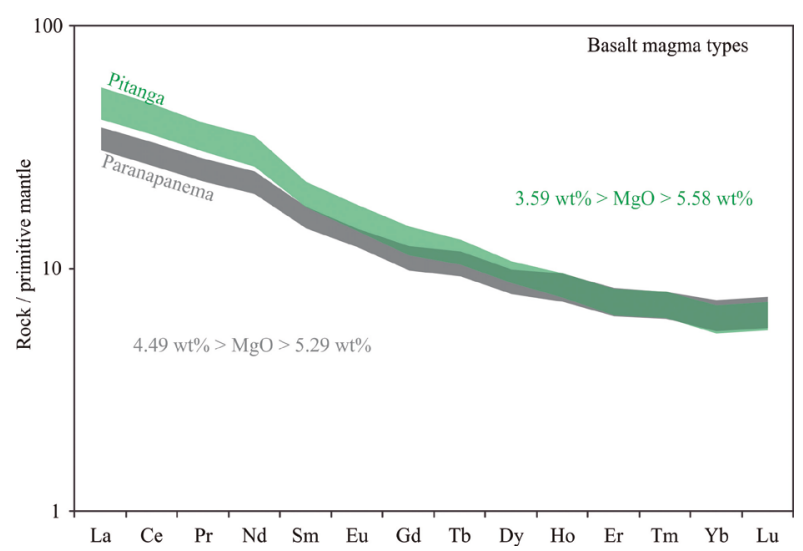

Figure 7. REE chondrite-normalized diagram with a range of concentration for the studied basalts associated with the Pitanga and Paranapanema rocks from the Paraná CFB. Normalization factors are from the primordial mantle of McDonough and Sun (1995). an amygdaloidal facies, not sampled for analysis. A 2 m-thick inter-layered pit 1 type basalt with contemporary sandstone was found at level $871 \mathrm{~m}$.

The two Pitanga type flow sequences show that pit 1 is more depleted than pit5 in $\mathrm{P}_{2} \mathrm{O}_{5}(0.49-0.51$ wt.\% vs. 0.730.81 wt.\%; Fig. 9A) and Sr (374-390 vs. 414-451 ppm; Fig. 7C), presenting also higher values of $\mathrm{TiO}_{2}(3.50-$ 3.56 wt. $\%$ vs. 3.30-3.32 wt.\%, Fig.7B) and similar $\mathrm{Zr} / \mathrm{Y}$ ratios $(6.73-7.07$ vs. $6.98-7.28$; Fig.7D).

\section{PAI borehole}

The PAI borehole is located northeastwards and $120 \mathrm{~km}$ away from the ALT borehole. It is at $686 \mathrm{~m}$ altitude, and the basalts are discordantly overlain by a $50 \mathrm{~m}$-thick sequence of

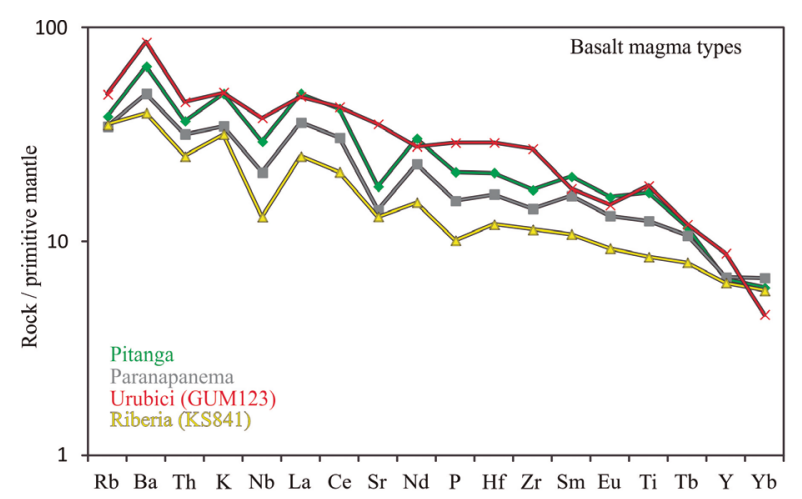

Figure 8. Diagram of incompatible elements normalized to primordial mantle (McDonough \& Sun 1995). The ratios presented in the diagram show the average of the representative samples calculated for the Pitanga and Paranapanema flows, while Urubici and Ribeira correspond to samples GUM123 and KS841 respectively.

Table 3. Compositional variation for selected elements of different sequences of basalt flows identified in the boreholes of the studied area. Caption: par (Paranapanema magma type); pit (Pitanga magma type); rib (Ribeira magma type); uru (Urubici magma type).

\begin{tabular}{l|c|c|c|c|c}
\hline Flow & $\mathbf{T i O}_{2}$ (wt.\%) & $\mathbf{M g O}(\mathbf{w t} . \%)$ & $\mathbf{P}_{\mathbf{2}} \mathbf{O}_{\mathbf{5}}$ (wt.\%) & $\mathbf{S r}$ (ppm) & $\mathbf{Z r / Y}$ \\
\hline par1 & $1.77-3.14$ & $4.32-7.47$ & $0.22-0.34$ & $216-458$ & $4.19-6.17$ \\
\hline par2 & $2.60-3.58$ & $4.18-5.58$ & $0.35-0.41$ & $303-524$ & $5.01-8.00$ \\
\hline pit1 & $3.35-4.23$ & $3.66-4.69$ & $0.48-0.52$ & $336-529$ & $4.65-7.91$ \\
\hline pit2 & $3.12-4.15$ & $3.60-5.22$ & $0.36-0.47$ & $346-564$ & $5.74-7.28$ \\
\hline pit3 & $3.15-3.80$ & $4.10-5.35$ & $0.36-0.42$ & $346-484$ & $5.74-6.63$ \\
\hline pit4 & $3.20-4.12$ & $3.54-4.53$ & $0.58-0.69$ & $346-580$ & $5.74-7.32$ \\
\hline pit5 & $3.20-3.32$ & $3.21-3.73$ & $0.73-0.85$ & $414-481$ & $5.94-7.28$ \\
\hline rib1 & $1.82-2.06$ & $5.33-5.65$ & $0.22-0.23$ & $230-252$ & $4.17-4.39$ \\
\hline uru1 & $3.82-3.97$ & $3.83-4.22$ & $0.63-0.64$ & $489-748$ & $6.67-8.05$ \\
\hline
\end{tabular}


Bauru sandstones, where a discordant contact occurs with basalt at $636 \mathrm{~m}$. There is intercalation with the sandstone of the Botucatu Formation at $496 \mathrm{~m}$ (25 m thick), overlain by a vesicular $30 \mathrm{~m}$-thick flow at the top, and another contact with contemporary sandstone at $466 \mathrm{~m}$ (Fig. 10A). Also, there is a sill in the Piramboia Formation (at least $4 \mathrm{~m}$ thick) close to the level $236 \mathrm{~m}$.

Geochemical data (Fig. 10A) show that the basaltic lava flows of pit1 type occur down to level $625 \mathrm{~m}$. Pit3 overlies them up to level $600 \mathrm{~m}$, and then pit2 type flow appears at $550 \mathrm{~m}$. The pit 1 sequence occurs again from level $550 \mathrm{~m}$ to $530 \mathrm{~m}$ whereas pit 4 appears downwards being underlain by sandstone at $496 \mathrm{~m}$. Pit2 lava flows take place between the Botucatu sandstone sequences ( $471-466 \mathrm{~m})$. A pit1 sill intrudes the Piramboia Formation at the bottom of the borehole.

Pit3 flows are depleted in $\mathrm{P}_{2} \mathrm{O}_{5}(0.36-0.40 \mathrm{wt} . \%)$ when compared to pit2 (0.43-0.48 wt.\%), pit1 (0.49-0.52 wt.\%) and pit4 (0.61-0.67 wt.\%). $\mathrm{TiO}_{2}$ concentrations (Fig. 8B) are higher in pit 4 (3.74-3.92 wt.\%) than in pit1 (3.56-3.80 wt.\%), pit 2 (3.34-3.76 wt.\%) and pit3 (3.15-3.55 wt.\%). Moreover, concentrations of $\mathrm{Sr}$ (Fig. 10C) and $\mathrm{Zr} / \mathrm{Y}$ ratios (Fig. 10D) are fairly close in all flow sequences: pit1 (342$393 \mathrm{ppm}$ and 6.1-6.8 for $\mathrm{Sr}$ and $\mathrm{Zr} / \mathrm{Y}$, respectively), pit2 (371-398 ppm, 6.2-3.3), pit3 (367-388 ppm, 6.1-6.4) and pit4 (349-405 ppm, 6.6-7.3).

All lava flows show vesiculated levels at their upper parts, with easy identification of the limits from each one.

\section{PIR borehole}

The PIR borehole is located $80 \mathrm{~km}$ south of PAI, with its top at level $585 \mathrm{~m}$ (altitude). The uppermost $10 \mathrm{~m}$ are composed of soil down to contact with basalt. Alternating sequences of Pitanga and Paranapanema appear, and the contact with sandstone occurs at $105 \mathrm{~m}$. There are no intercalations with sandstones, but there are sheet flow zones between $269 \mathrm{~m}$ and $200 \mathrm{~m}$, with multiple vesicular layers that had to be avoided for the geochemical analysis. In the upper part, there are
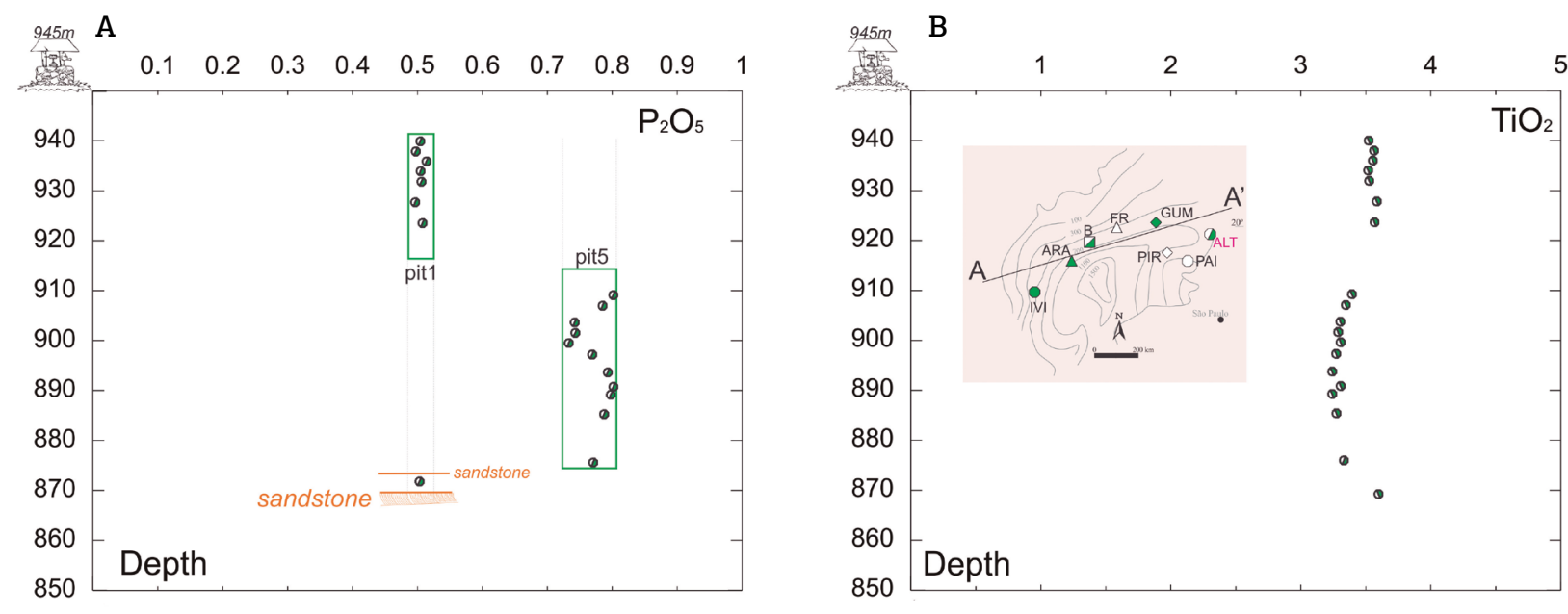

C
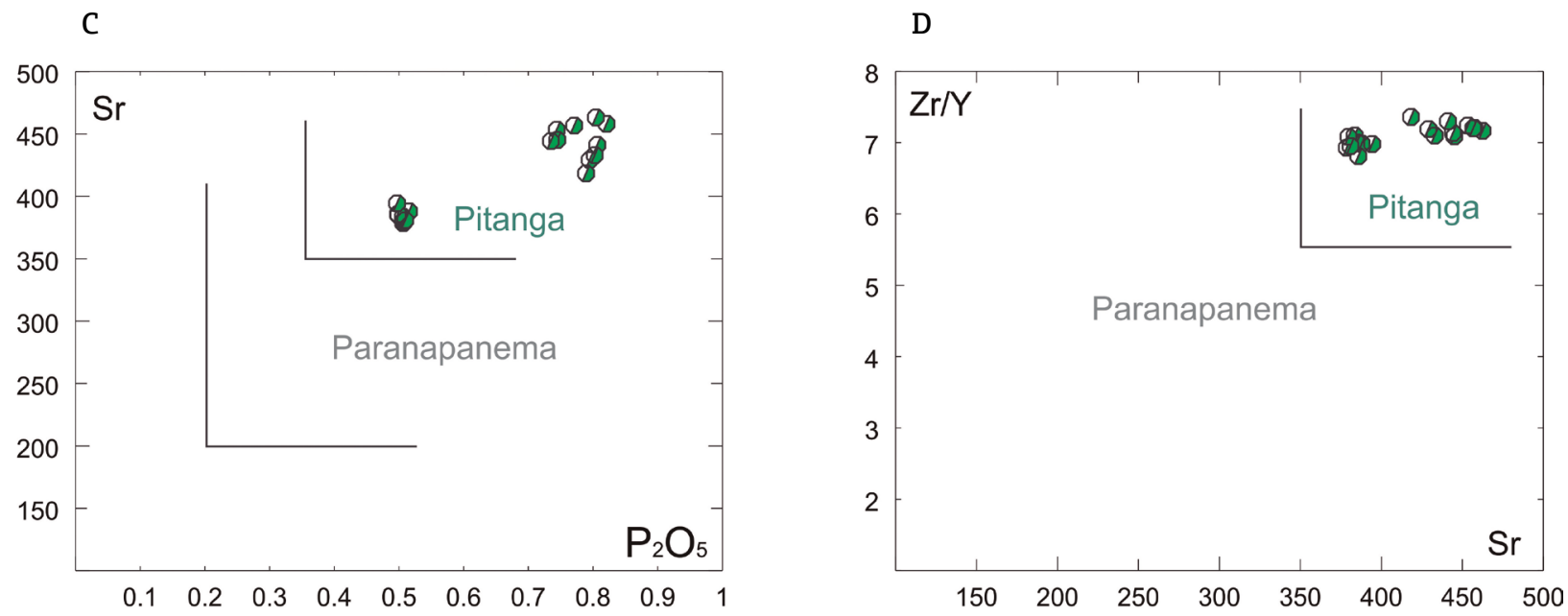

Figure 9. Selected variation diagrams illustrating distinctions between flow sequences in ALT borehole: (A) Depth vs. $\mathrm{P}_{2} \mathrm{O}_{5}$; (B) Depth vs. $\mathrm{TiO}_{2}$; (C) $\mathrm{P}_{2} \mathrm{O}_{5}$ vs. Sr; (D) $\mathrm{Sr}$ vs. $\mathrm{Zr} / \mathrm{Y}$. Oxides in wt.\%, trace elements in ppm, depth in meters. 
pit1-type basalts up to level $443 \mathrm{~m}$, preceded by pit 2 at to $407 \mathrm{~m}$. The par1 type occurs approximately between levels $407 \mathrm{~m}$ to $305 \mathrm{~m}$.

Pit2 flows occur at 305-270 $\mathrm{m}$ below par1, being underlain by a sheet flow zone with pit 1 , pit 2 and pit 3 intercalations. Pit3 underlays the sheet flow zone at 200-105 m (Fig. 11A).

Regarding the geochemical compositions, pit1 lavas are enriched in $\mathrm{P}_{2} \mathrm{O}_{5}(0.47-0.51$ wt.\%, Fig. $11 \mathrm{~A})$ and $\mathrm{TiO}_{2}$ (3.67-4.05 wt.\%, Fig 11b) when compared to pit2 (0.470.48 wt. $\% ; 3.66-3.82$ wt.\%) and pit3 lavas (0.39-0.43 wt. $\%, 3.41-3.80 \mathrm{wt} . \%$, respectively). Concerning the trace elements, $\mathrm{Sr}$ and $\mathrm{Zr} / \mathrm{Y}$ are higher in pit $1386-463 \mathrm{ppm}$ and 6.2-6.8, Figs. 9C, 9D) than in pit2 (353-398 ppm, 5.9-6.3) and pit3 (353-386 ppm ; 6.1-6.5).

The Paranapanema magma type (par1) shows a strong $\mathrm{P}_{2} \mathrm{O}_{5}$ depletion (0.26-0.34 wt.\%, Fig. 9A) when compared to the Pitanga type. The concentration of $\mathrm{TiO}_{2}(2.03-2.95$ wt.\%), Sr (216-321 ppm) and $\mathrm{Zr} / \mathrm{Y}$ ratios (4.5-5.5) are also lower (Figs. 11B, 11C, 11D).

\section{GUM borehole}

GUM is the northernmost borehole among the studied ones. It is located $80 \mathrm{~km}$ away from PIR borehole at level $495 \mathrm{~m}$ (altitude). There is $20 \mathrm{~m}$ of soil, and the basalt reaches a total thickness of $405 \mathrm{~m}$. The contact with the Botucatu Formation sandstones occurs at $70 \mathrm{~m}$ (altitude).

In the upper part, there is a sequence of pit3-type lavas down to level $350 \mathrm{~m}$, preceded by pit 4 and pit 1 , down to level 250 and $150 \mathrm{~m}$, respectively. At the bottom, uru 1 occurs with approximately $30 \mathrm{~m}$ of thickness, as shown in Fig. 12A. The occurrence of the Urubici magma type, uru1 (Figs. 12A, 12B), was identified by two samples (top and bottom) of the same flow, with $\mathrm{TiO}_{2}=3.95-3.97 \mathrm{wt} . \% ; \mathrm{P}_{2} \mathrm{O}_{5}=$ 0.63-0.64 wt.\%; $\mathrm{Sr}=748-731 \mathrm{ppm}$ and $\mathrm{Zr} / \mathrm{Y}=7.6-8.1$.

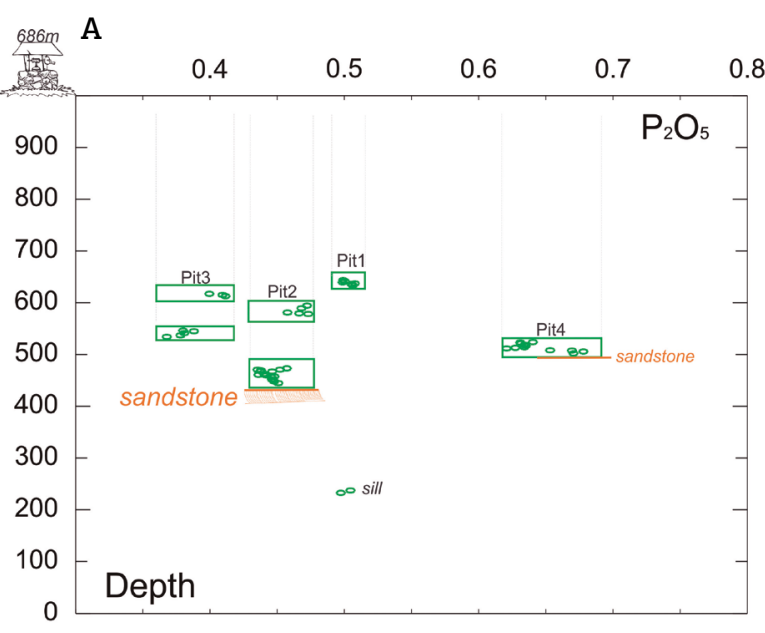

C

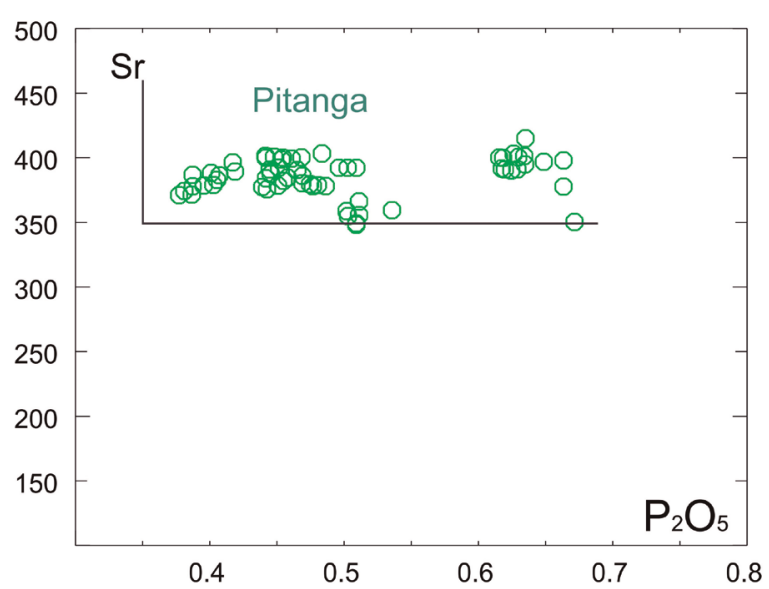

B

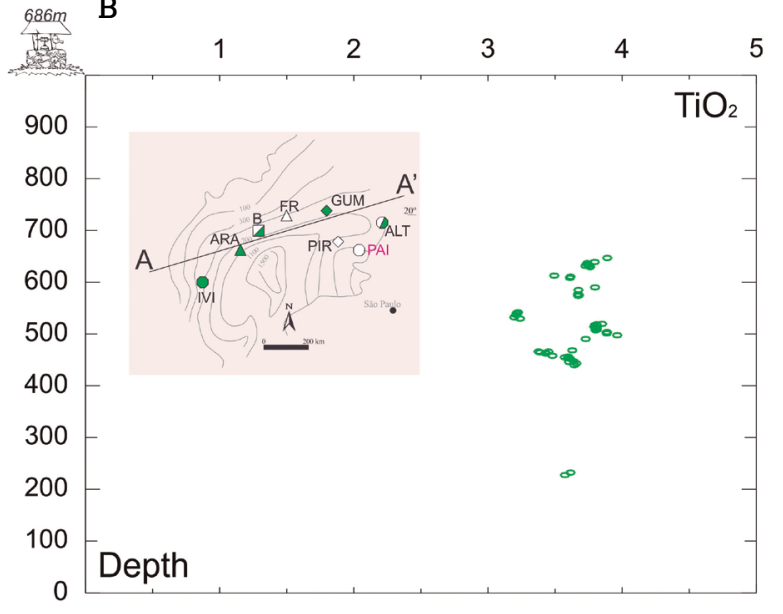

D

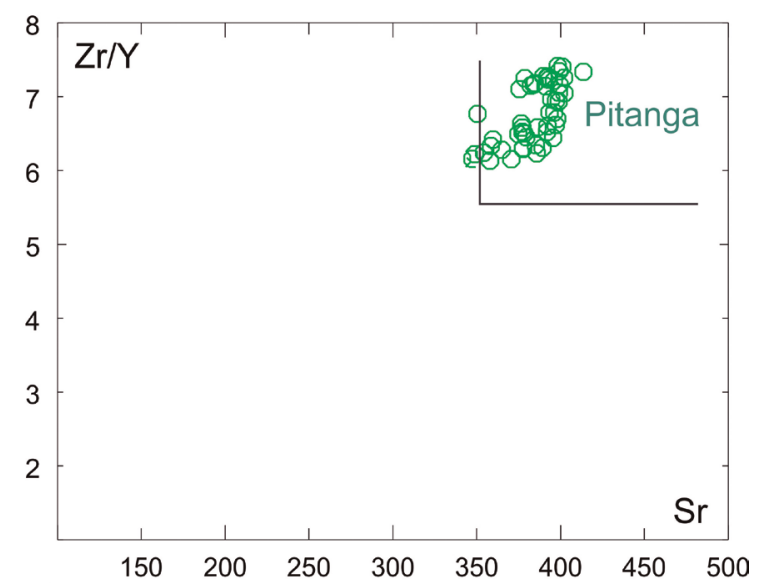

Figure 10. Selected variation diagrams illustrating distinctions between flow sequences in PAI borehole: (A) Depth vs. $\mathrm{P}_{2} \mathrm{O}_{5}$; (B) Depth vs. $\mathrm{TiO}_{2}$; (C) $\mathrm{P}_{2} \mathrm{O}_{5}$ vs. Sr; (d) $\mathrm{Sr}$ vs. $\mathrm{Zr} / \mathrm{Y}$. Oxides in wt.\%, trace elements in ppm, depth in meters. 
Pit4 type is richer in $\mathrm{P}_{2} \mathrm{O}_{5}(0.62-0.66$ wt.\%, Fig. 12A) and $\mathrm{TiO}_{2}(3.82-3.86$ wt. $\%$, Fig. $12 \mathrm{~B})$ than pit $1\left(\mathrm{P}_{2} \mathrm{O}_{5}=\right.$ $0.49-0.51$ wt. $\% ; \mathrm{TiO}_{2}=3.51-3.56$ wt. $\left.\%\right)$ and pit3 $\left(\mathrm{P}_{2} \mathrm{O}_{5}=\right.$ $0.31-0.44$ wt. $\% ; \mathrm{TiO}_{2}=2.89-3.63$ wt. $\left.\%\right)$. On the other hand, the values of $\mathrm{Sr}$ and $\mathrm{Zr} / \mathrm{Y}$ (Figs. 10C, 10D) are similar: pit4 (189-496 ppm, 6.6-7.0); pit1 (416-421 ppm, 6.6-6.9) and pit3 (458-524 ppm, 5.4-6.6).

Surface sample KS616, collected at level 593 m, presents a similar composition to pit3 $\left(\mathrm{P}_{2} \mathrm{O}_{5}=0.39 \mathrm{wt} . \%, \mathrm{TiO}_{2}=4.42\right.$ wt. $\%, \mathrm{Sr}=561 \mathrm{ppm}, \mathrm{Zr} / \mathrm{Y}=6.4)$. On the other hand, surface sample KS618, collected at level $742 \mathrm{~m}$, at the western limit of the flow and in contact with the Botucatu Formation, has a similar composition to uru $1\left(\mathrm{P}_{2} \mathrm{O}_{5}=0.63 \mathrm{wt} . \% ; \mathrm{TiO}_{2}=4.03\right.$ wt. $\%$; $\mathrm{Sr}=720$ ppm; $\mathrm{Zr} / \mathrm{Y}=7.2$, Fig. 12A, 12B, 12C, 12D).

\section{FR borehole}

The FR, the reference borehole, is located $300 \mathrm{~km}$ away from the GUM borehole, with its top at $540 \mathrm{~m}$ (altitude).
As aforementioned, it constitutes a sequence with intercalations between Pitanga and Paranapanema magma types. The limits are marked by vesicular zones and a massive sill between flows.

The presence of such type of intrusion between flow limits is not unprecedented in the literature on volcanic fissural systems. It has already been described for flows in southern PCFB by Peate \& Hawkesworth (1996) and in Iceland by Gudmundsson et al. (2014).

No sandstone intercalations occur and the sequence begins at level $500 \mathrm{~m}$ after $40 \mathrm{~m}$ of sandstone associated with the Bauru Sub-Basin. The borehole ends at $-320 \mathrm{~m}$ in contact with the Botucatu Formation sandstone (Fig. 13A).

From top towards bottom, the sequence of lavas is represented by pit1 (level $500 \mathrm{~m}$ ); par1 (level $380 \mathrm{~m}$ ); pit1 (level $256 \mathrm{~m}$ ); pit2 (level $174 \mathrm{~m}$ ); pit3 (level $90 \mathrm{~m}$ ); pit4 (level $30 \mathrm{~m}$ ); pit1 (level -36 m); par1 (level -144 m); pit3

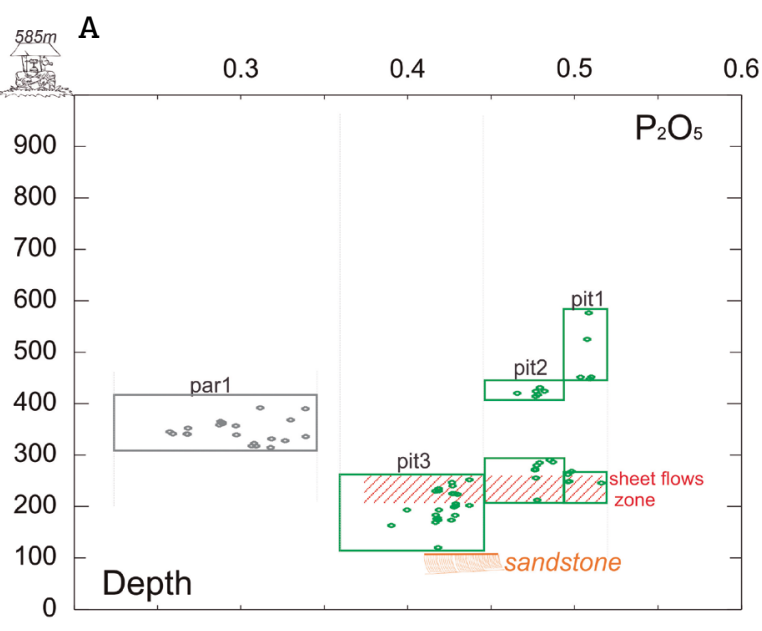

C

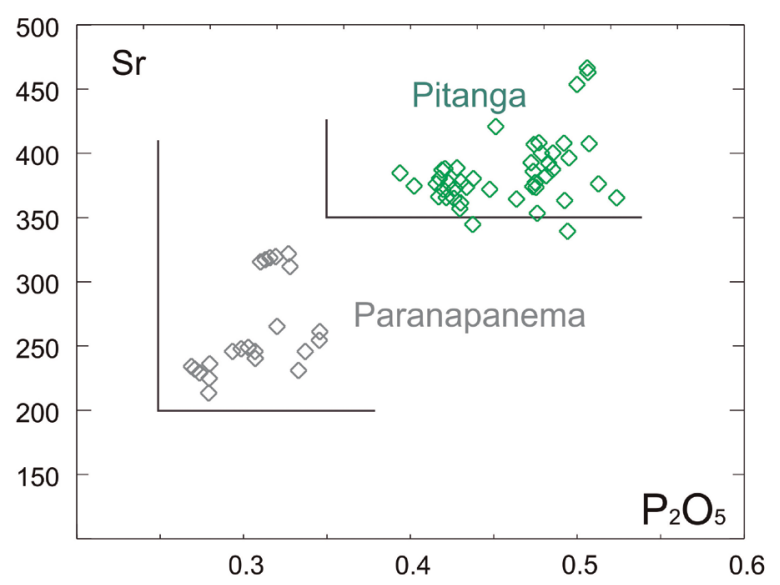

B

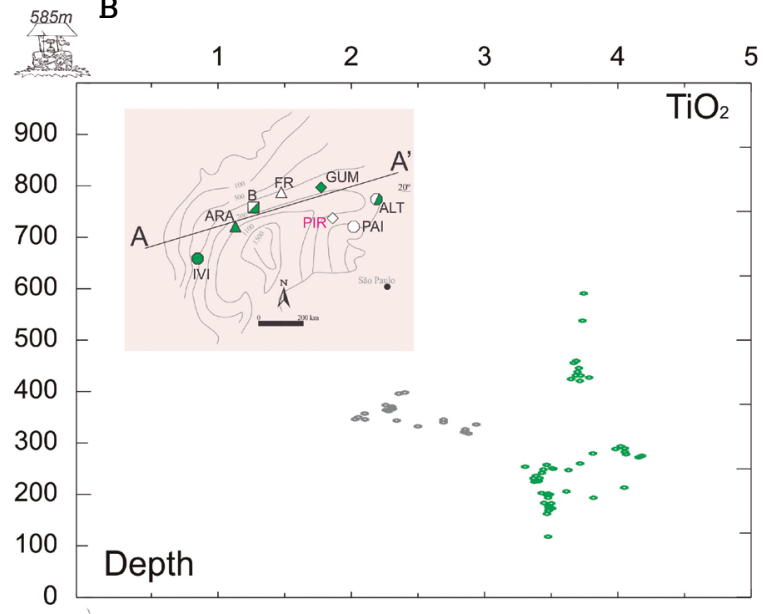

D

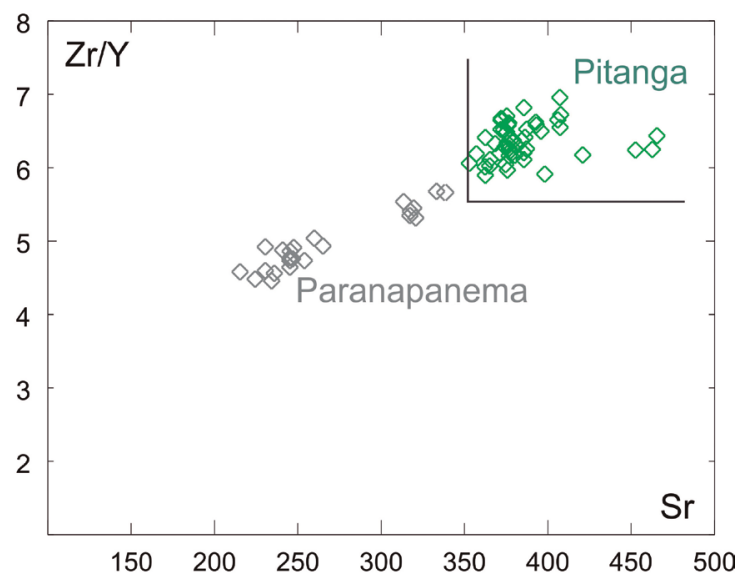

Figure 11. Selected variation diagrams illustrating distinctions between flow sequences in PIR borehole: (A) Depth vs. $\mathrm{P}_{2} \mathrm{O}_{5}$; (B) Depth vs. $\mathrm{TiO}_{2}$; (C) $\mathrm{P}_{2} \mathrm{O}_{5}$ vs. $\mathrm{Sr}$; (D) $\mathrm{Sr}$ vs. $\mathrm{Zr} / \mathrm{Y}$. Oxides in wt.\%, trace elements in ppm, depth in meters. 
(level -196 m); par2 (level -260 m). The sill occurs at level $340 \mathrm{~m}$ between the last two sequences of flows, and is less than $1 \mathrm{~m}$ thick.

The pit 4 flows are more enriched in $\mathrm{P}_{2} \mathrm{O}_{5}(0.62-0.66 \mathrm{wt} . \%$; Fig 13a) than pit1 (0.48-0.52 wt.\%), pit2 (0.44-0.47 wt.\%) and pit3 (0.38-0.44 wt.\%). Pit1 is more enriched in $\mathrm{TiO}_{2}$ (3.35-4.23wt.\%, Fig 13b) and Zr/Y (5.9-7.0, Fig 13d) than pit4 (3.83-3.89 wt.\%, 6.8-7.0), pit2 (3.50-3.84 wt.\%, 6.1-6.5) and pit3 (3.20-3.49wt.\%, 6.1-6.5). However, the last one seems to be more enriched in $\mathrm{Sr}$ (319-414 ppm; Fig. 13C) than pit1 (379-414 ppm), pit2 (378-405 ppm) and pit4 (382-399 ppm).

Concerning the Paranapanema magma type, the difference between the par 1 and par2 flows is given by the concentration of $\mathrm{P}_{2} \mathrm{O}_{5}$, which is more enriched in par2 than in par1 (0.35-0.39 wt.\% vs. 0.29-0.33 wt.\%, Fig. $13 \mathrm{~A})$. On the other hand, $\mathrm{TiO}_{2}, \mathrm{Sr}$ and $\mathrm{Zr} / \mathrm{Y}$ are similar
(2.60-2.93 wt.\% vs. $2.53-2.95$ wt. $\%, 303-330$ ppm vs. 322-334 ppm, 5.0-5.4 vs. 5.2-5.6, respectively; Figs. 13B, 13C, 13D).

Two samples from the sill located between pit 1 and par1, at the top of the sequence, have $\mathrm{P}_{2} \mathrm{O}_{5}$ concentrations (0.40 and 0.41 wt.\%; Fig. 13A) significantly different from those observed in pit 1 and par1. The concentrations of $\mathrm{TiO}_{2}$ (0.39 and 0.40 wt.\%, Fig 13.b) and $\mathrm{Zr} / \mathrm{Y}$ ratios (6.2 and 6.3, Fig. 13D) are close to those of pit1 and pit2, while $\mathrm{Sr}$ is close only to pit1 (Fig. 13C).

Three surface samples were also shown in Figs. $13 \mathrm{C}$ and 13D. Sample KS 716 (354 m) has $\mathrm{P}_{2} \mathrm{O}_{5}$ (0.44 wt.\%), $\mathrm{TiO}_{2}$ (1.91 wt.\%), Sr (424 ppm) and $\mathrm{Zr} / \mathrm{Y}$ (6.2) similar to those of pit2. The samples KS 713 (345 m) and KS 714 (344 m) are less enriched and similar to par $1\left(\mathrm{P}_{2} \mathrm{O}_{5}=0.22\right.$ and 0.22 wt. $\%, \mathrm{TiO}_{2}=1.94$ and 1.92 wt. $\%, \mathrm{Sr}=341$ and $328 \mathrm{ppm}$, $\mathrm{Zr} / \mathrm{Y}=5.0$ and 5.1 ).
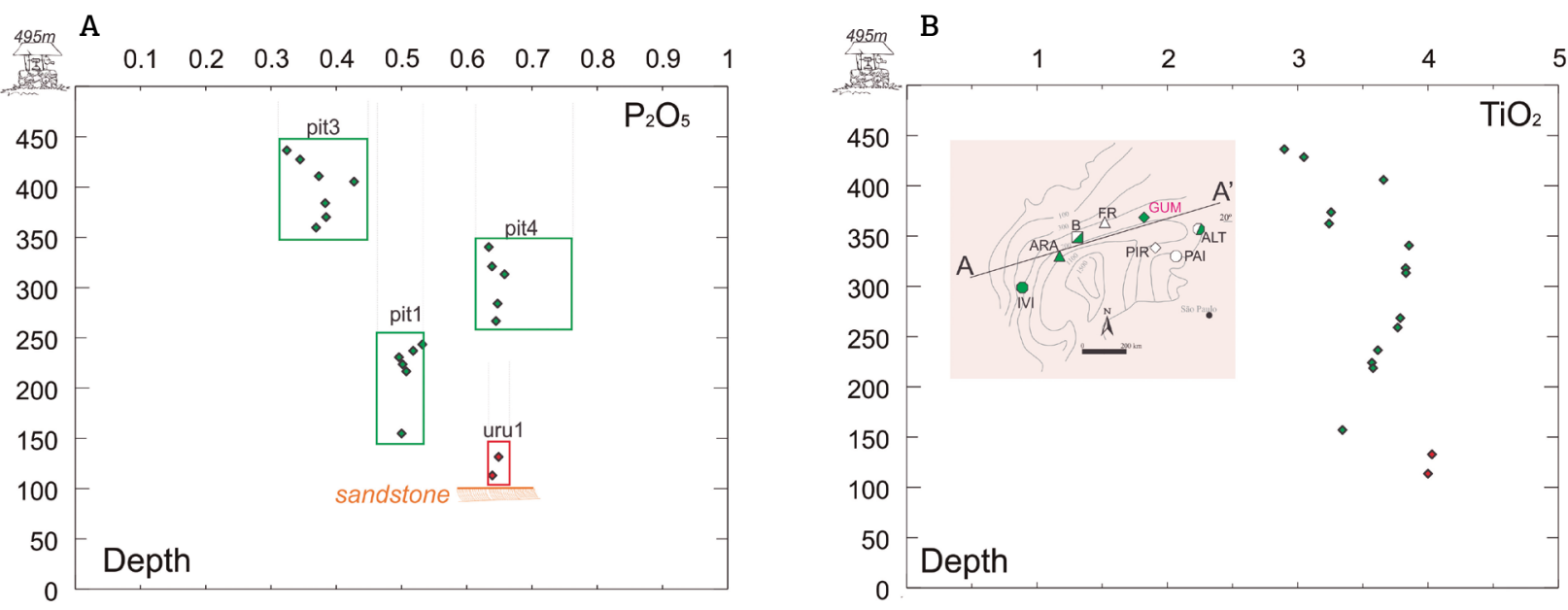

C
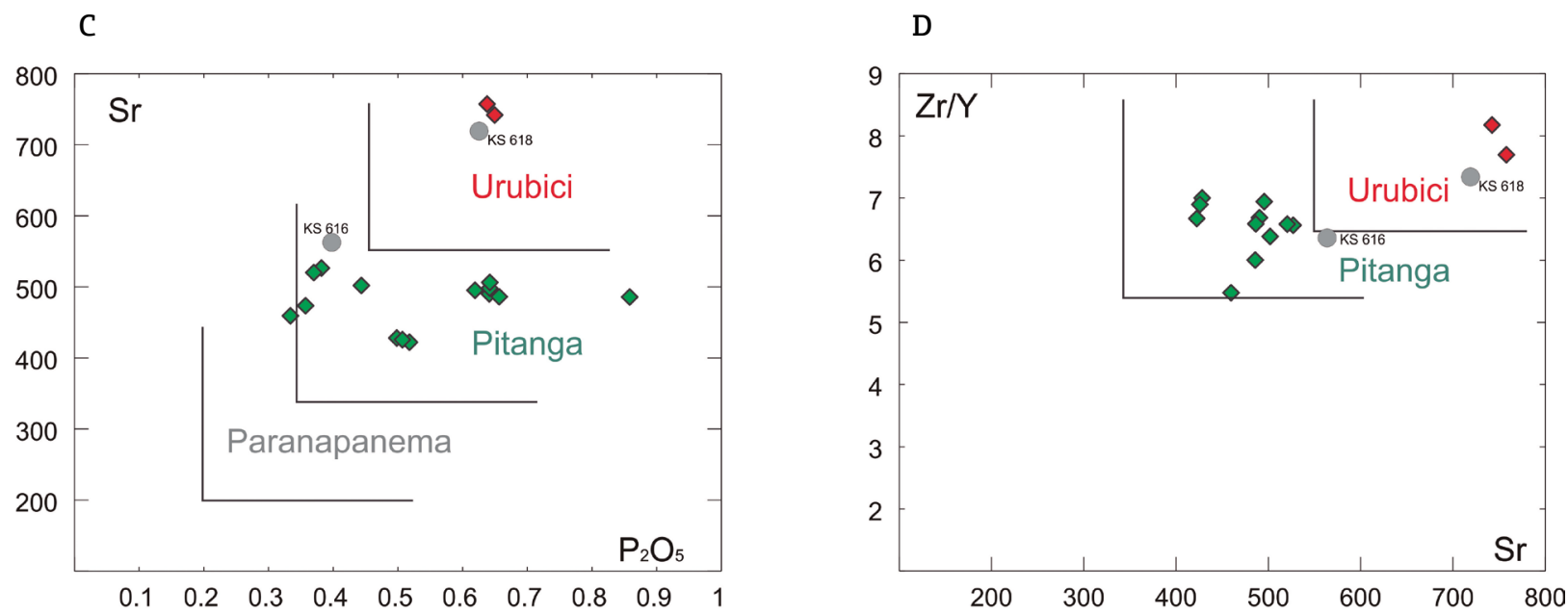

Figure 12. Selected variation diagrams illustrating distinctions between flow sequences in GUM borehole and surface samples: (A) Depth vs. $\mathrm{P}_{2} \mathrm{O}_{5}$; (B) Depth vs. $\mathrm{TiO}_{2}$; (C) $\mathrm{P}_{2} \mathrm{O}_{5}$ vs. Sr; (D) Sr vs. Zr/Y. Oxides in wt.\%, trace elements in ppm, depth in meters. 


\section{B borehole}

B borehole is $120 \mathrm{~km}$ west of FR borehole, with its top at level $370 \mathrm{~m}$ (altitude), and also features a wide variety of flows covered by 8 meters of Bauru Sub-Basin sandstones. The basalt occurs from level $350 \mathrm{~m}$ down to $-430 \mathrm{~m}$ (780 m-thick), at a concordant contact with the Botucatu Formation (Fig. 14A).

There are no intercalations with contemporary sandstone. Flows are massive with vesicular levels at the upper part, and similarly to the FR borehole, there is also a massive sill, less than $4 \mathrm{~m}$ thick, close to the $-236 \mathrm{~m}$ level between two flows (pit1 and par1).

From the top at $350 \mathrm{~m}$ to $250 \mathrm{~m}$ flows are the par 1 type, preceded by pit1 $(194 \mathrm{~m})$, pit3 $(-150 \mathrm{~m})$, par1 $(-218 \mathrm{~m})$, pit1 $(-300 \mathrm{~m})$ and pit $4(-430 \mathrm{~m})$.

The pit 4 is the most enriched in $\mathrm{P}_{2} \mathrm{O}_{5}(0.58-0.69 \mathrm{wt} . \%$, Fig 14a), $\mathrm{TiO}_{2}$ (3.66-4.12 wt.\%, Fig. 14B), Sr (501-580 ppm,
Fig. 14C) and $\mathrm{Zr} / \mathrm{Y}$ (6.5-7.1; Fig. 14D) when compared to pit1 $\left(\mathrm{P}_{2} \mathrm{O}_{5}: 0.46-0.52 \mathrm{wt} . \%, \mathrm{TiO}_{2}: 3.62-3.98 \mathrm{wt} . \%\right.$, Sr: 400-554 ppm, Zr/Y: 4.7-6.7), pit3 ( $\mathrm{P}_{2} \mathrm{O}_{5}: 0.36-0.42$ wt.\%, $\mathrm{TiO}_{2}: 3.22-3.58$ wt.\%; Sr: 436-484 ppm; Zr/Y: 5.5-6.5) and par1 $\left(\mathrm{P}_{2} \mathrm{O}_{5}: 0.22-0.31\right.$ wt.\%; $\mathrm{TiO}_{2}: 1.85-2.89$ wt.\%; Sr: 305-458 ppm; Zr/Y: 4.5-5.4).

The sill (Fig. 14A) is represented by two samples with a composition similar to pit3: $\mathrm{P}_{2} \mathrm{O}_{5}(0.41$ and $0.39 \mathrm{wt} . \%), \mathrm{TiO}_{2}(3.58$ and 3.58 wt.\%), Sr (448 and $449 \mathrm{ppm}), \mathrm{Zr} / \mathrm{Y}$ (6.3 and 6.2).

\section{ARA borehole}

The ARA borehole is located at level $342 \mathrm{~m}$ (altitude), comprising the fewest samples when compared to others, and $27 \mathrm{~km}$ away from B borehole. The sequence of basaltic flows ends at level $308 \mathrm{~m}$ and is overlain by $34 \mathrm{~m}$ of Bauru Sub-Basin sandstone. It starts at the $-613 \mathrm{~m}$ level in contact with the Botucatu Formation sandstone (Fig. 15A).
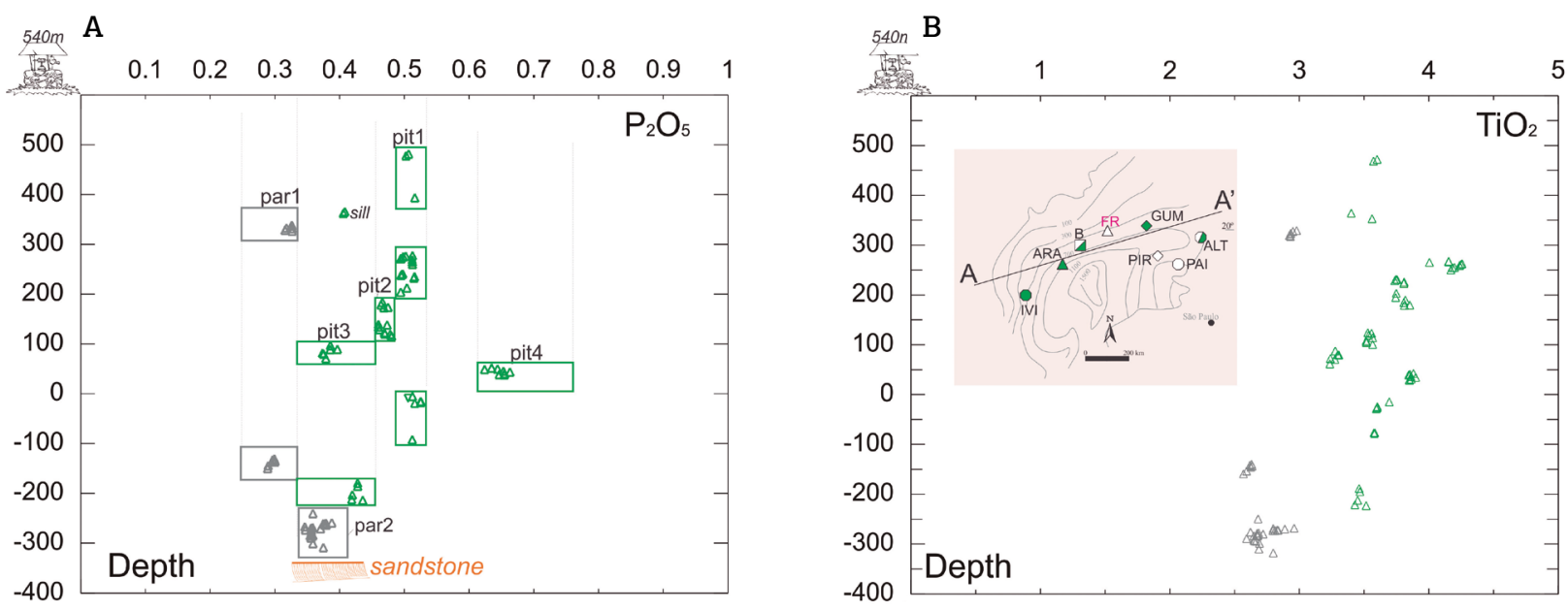

C
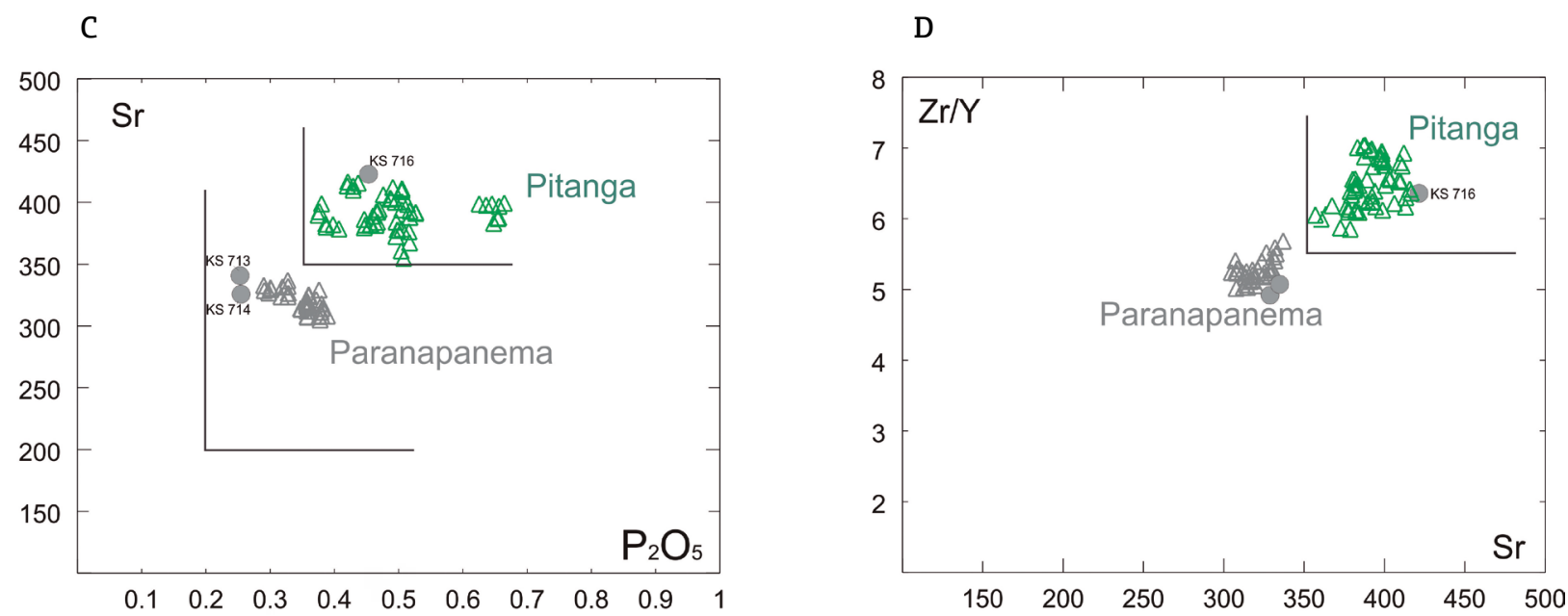

Figure 13. Selected variation diagrams illustrating distinctions between flow sequences in FR borehole and samples surface: (A) Depth vs. $\mathrm{P}_{2} \mathrm{O}_{5}$; (B) Depth vs. $\mathrm{TiO}_{2}$; (C) $\mathrm{P}_{2} \mathrm{O}_{5}$ vs. Sr; (D) Sr vs. Zr/Y. Oxides in wt.\%, trace elements in $\mathrm{ppm}$, depth in meters. 
This borehole has already been used by Torres et al. (2008) and is of great importance for the continuity of the flows related to the closest boreholes, despite the small number of suitable samples for geochemical analysis.

Thus, the sequence bears par1 flows up to approximately $110 \mathrm{~m}$, preceded by a sample of pit $1(28 \mathrm{~m})$, pit3 $(-112 \mathrm{~m})$, par1 $(-368 \mathrm{~m})$, pit1 $(-562 \mathrm{~m})$ and a pit4 sample close to the contact $(-600 \mathrm{~m})$. Because of the small number of samples, thicknesses of flow sequences are approximated and supported by the petrographic analyzes of the chips.

Flows from pit 1 are more enriched in $\mathrm{P}_{2} \mathrm{O}_{5}(0.47-$ 0.52 wt.\%, Fig. 15A), $\mathrm{TiO}_{2}$ (3.12-366 wt.\%, Fig. 15B) and $\mathrm{Sr}$ (406-492 ppm, Fig. 15C) than pit3 ( $\mathrm{P}_{2} \mathrm{O}_{5} 0.34-0.36$ wt.\%; $\mathrm{TiO}_{2}$ 3.01-3.23 wt.\%; Sr 309-418 ppm) and par1 ( $\mathrm{P}_{2} \mathrm{O}_{5}$ 0.22-0.33 wt.\%, $\mathrm{TiO}_{2} 1.77-2.81$ wt.\%, Sr 277-421 ppm). The $\mathrm{Zr} / \mathrm{Y}$ (Fig. 15D) ratios are quite similar, but still slightly higher in pit3 (5.3-8.0) than pit1 (5.1-7.9) and par1 (4.2-6.2).
Finally, the pit4 sample shows $\mathrm{P}_{2} \mathrm{O}_{5}=0.59$ wt. $\%, \mathrm{TiO}_{2}=$ 4.03 wt. $\%, \mathrm{Sr}=580 \mathrm{ppm}$, and $\mathrm{Zr} / \mathrm{Y}=7.1$.

\section{IVI borehole}

The IVI borehole is located in the westernmost part of the area, close to the border of Paraná Basin, $360 \mathrm{~km}$ from the ARA borehole, crossing the Paraná River (Fig. 1). The contact with the basalt occurs at $190 \mathrm{~m}$ after $193 \mathrm{~m}$ of Bauru Sub-Basin sandstone, while the contact with the Botucatu Formation sandstone occurs at $-563 \mathrm{~m}$ (Fig. 16A), adding $753 \mathrm{~m}$ of lava flows.

Intercalation with contemporary sandstone is observed at level $-350 \mathrm{~m}$ (Fig. 16A), less than $2 \mathrm{~m}$ thick, separating two pit 4 and pit 1 flow sequences. All sequences were identified by vesicular layers.

The flow sequence starts with par1 up to level $83 \mathrm{~m}$, preceded by rib1 $(77 \mathrm{~m})$, par1 $(-35 \mathrm{~m})$, rib1 $(-203 \mathrm{~m})$, pit 4 $(-355 \mathrm{~m})$, pit1 $(-545 \mathrm{~m})$, and pit4 $(-563 \mathrm{~m})$.

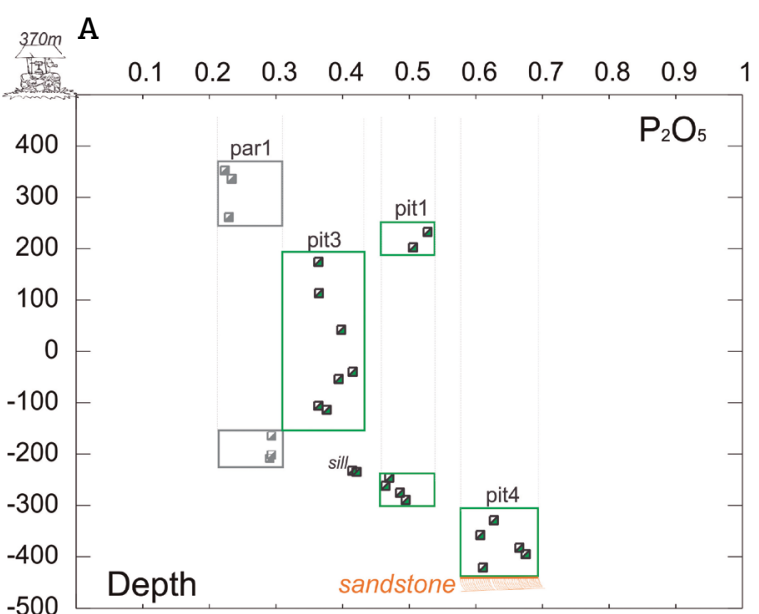

C

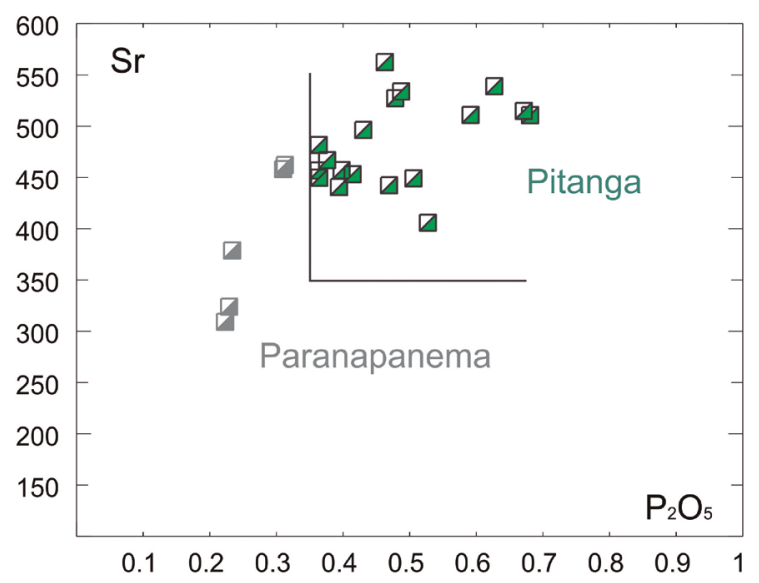

B

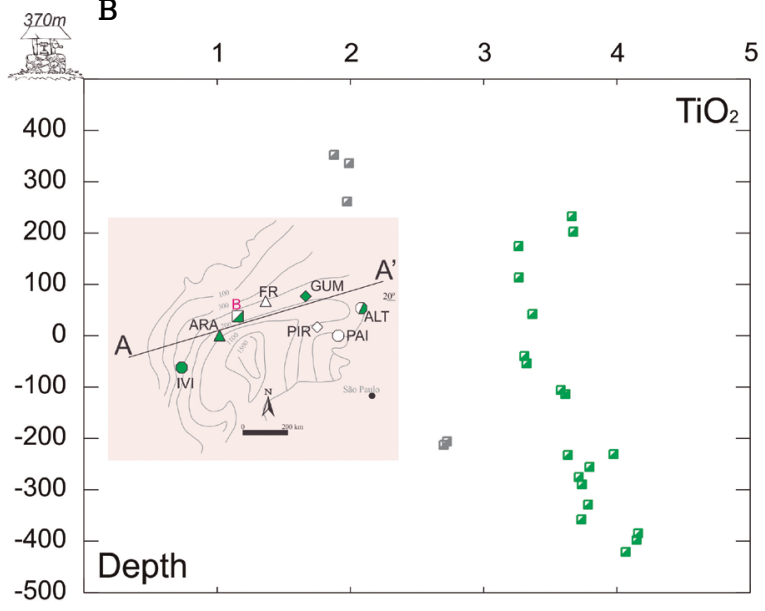

D

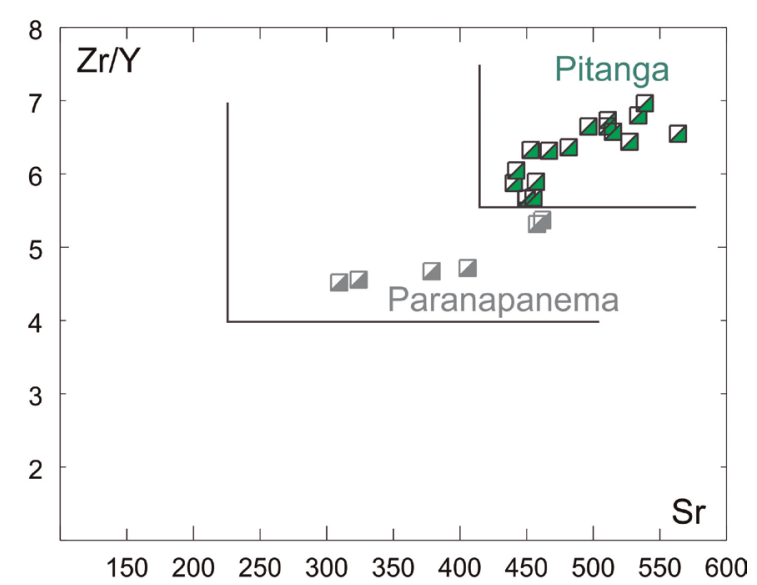

Figure 14. Selected variation diagrams illustrating distinctions between flow sequences in $\mathrm{B}$ borehole and samples surface: (A) Depth vs. $\mathrm{P}_{2} \mathrm{O}_{5}$; (B) Depth vs. $\mathrm{TiO}_{2}$; (C) $\mathrm{P}_{2} \mathrm{O}_{5}$ vs. Sr; (D) Sr vs. Zr/Y. Oxides in wt.\%, trace elements in ppm, depth in meters. 
Pit4 is more enriched in $\mathrm{P}_{2} \mathrm{O}_{5}(0.61-0.68$ wt.\%, Fig. 16A), $\mathrm{TiO}_{2}$ (3.61-4.09 wt.\%, Fig. 16B), Sr (346$412 \mathrm{ppm}$, Fig. 16C) and $\mathrm{Zr} / \mathrm{Y}(6.2-6.9$, Fig. 16D) than pit1 $\left(\mathrm{P}_{2} \mathrm{O}_{5}\right.$ 0.47-0.48 wt.\%; $\mathrm{TiO}_{2} 3.54-3.73$ wt.\%; $\mathrm{Sr}$ 352-374 ppm; $\mathrm{Zr} / \mathrm{Y}$ 6.3-6.6) and par1 $\left(\mathrm{P}_{2} \mathrm{O}_{5} 0.27-\right.$ 0.32 wt.\%; $\mathrm{TiO}_{2} 2.32-2.66$ wt.\%; Sr 226-258 ppm; $\mathrm{Zr} / \mathrm{Y}$ 4.5-4.7).

The rib1 samples are more depleted in $\mathrm{P}_{2} \mathrm{O}_{5}(0.22-0.23$ wt.\%), $\mathrm{TiO}_{2}(1.82-2.06$ wt.\%), $\mathrm{Sr}(230-252 \mathrm{ppm}$ ) and $\mathrm{Zr} / \mathrm{Y}$ (4.2-4.4) than all other samples.

Two surface samples (Fig. 2) were also collected to the west of IVI borehole: KS 841, in contact with the Botucatu Formation at $496 \mathrm{~m}$, and KS 730 at level $399 \mathrm{~m}$. KS 841 has similar composition to rib1 $\left(\mathrm{P}_{2} \mathrm{O}_{5} 0.22 \mathrm{wt} . \%\right.$, $\mathrm{TiO}_{2} 1.83$ wt.\%, Sr 276 ppm, $\mathrm{Zr} / \mathrm{Y}$ 4.4), while KS 730 is similar to pit4 $\left(\mathrm{P}_{2} \mathrm{O}_{5} 0.68 \mathrm{wt} . \%, \mathrm{TiO}_{2} 3.58 \mathrm{wt} . \%, \mathrm{Sr}\right.$ $417 \mathrm{ppm}, \mathrm{Zr} / \mathrm{Y}$ 6.8).

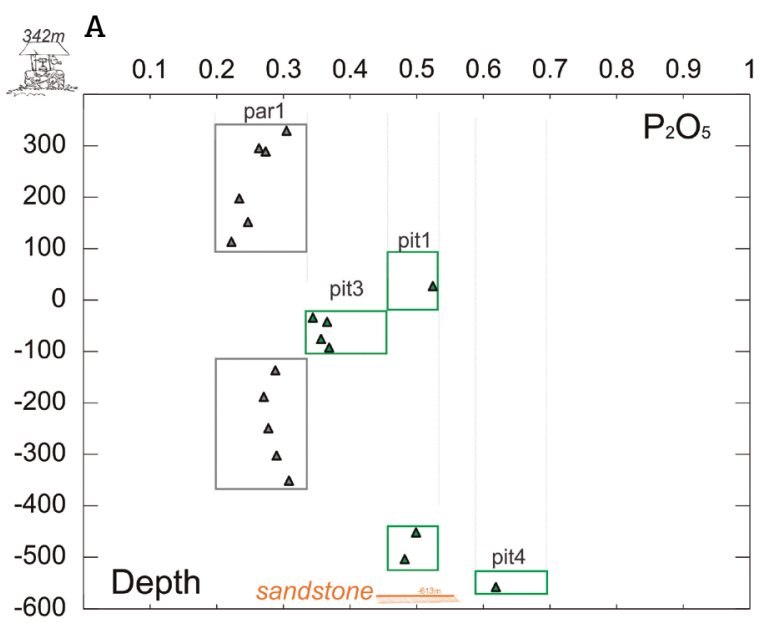

C

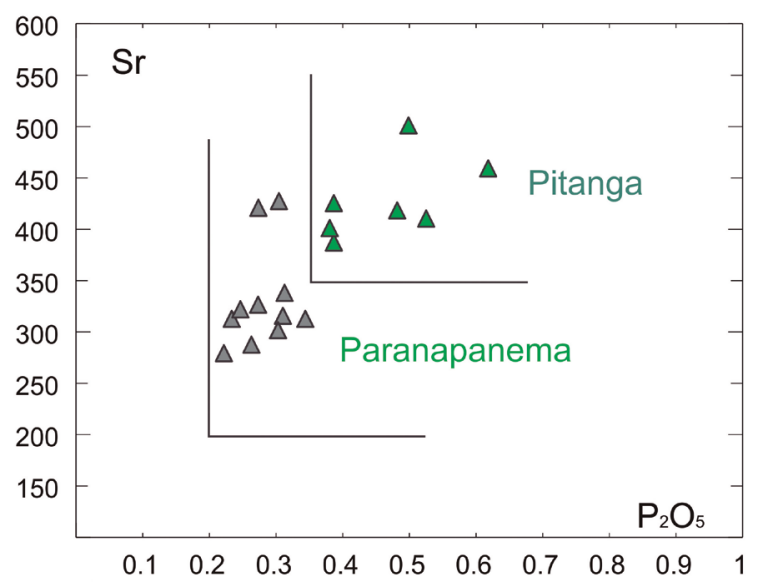

\section{DISCUSSION AND CONCLUSIONS}

The different sequences of Paranapanema and Pitanga magma types (par1, par2, pit1-pit5), identified by the contents of $\mathrm{P}_{2} \mathrm{O}_{5}, \mathrm{TiO}_{2}$ and $\mathrm{Sr}$, and $\mathrm{Zr} / \mathrm{Y}$ ratios, can be related to transitional compositions between the two magmas. This interpretation is also shown in Cox and Hawkesworth (1985), who described similar problems in defining the boundaries of different magma types in the Deccan.

The data obtained reinforce previous studies (e.g. Piccirillo \& Melfi 1988, Marques et al. 1999, Rocha-Júnior et al. 2013), which demonstrated the cogeneticity (common mantle source) between the two high titanium magmas (Pitanga and Paranapanema). Distribution patterns for REE and other incompatible trace elements showed that there are not significant geochemical differences between Pitanga (pit) and

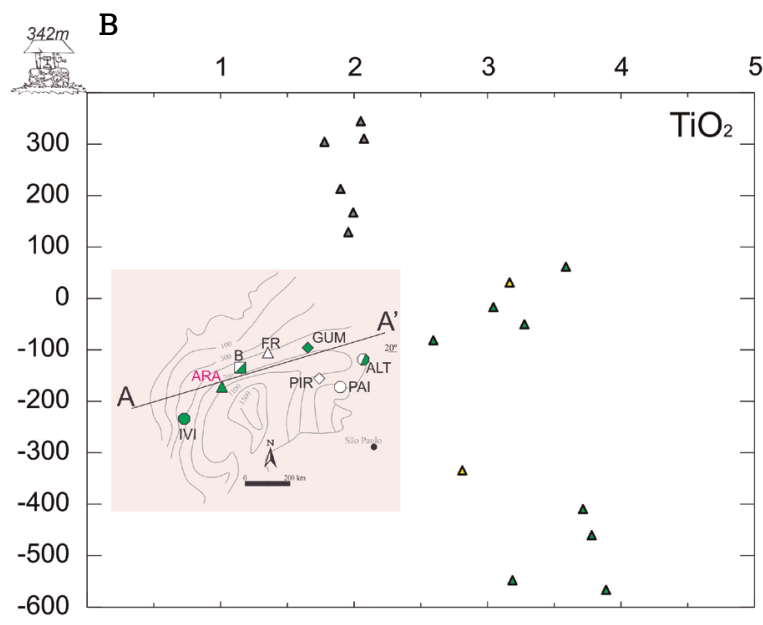

D

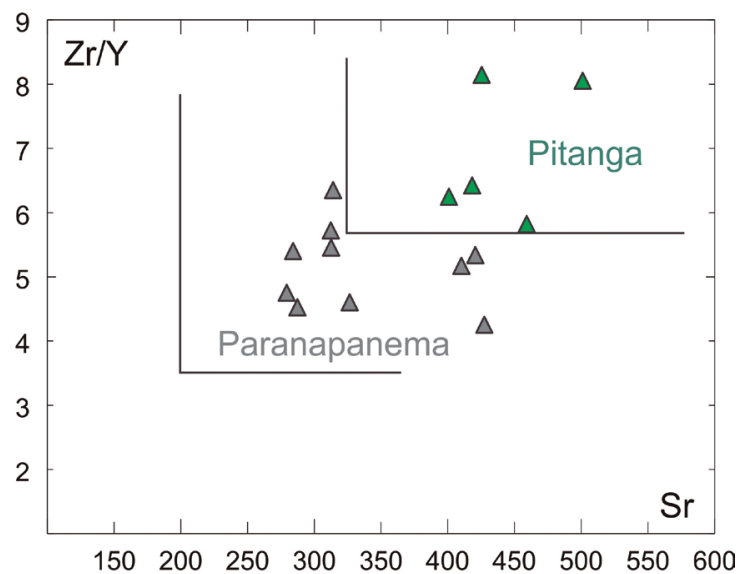

Figure 15. Selected variation diagrams illustrating distinctions between flow sequences in ARA borehole: (A) Depth vs. $\mathrm{P}_{2} \mathrm{O}_{5}$; (B) Depth vs. $\mathrm{TiO}_{2}$; (C) $\mathrm{P}_{2} \mathrm{O}_{5}$ vs. Sr; (D) $\mathrm{Sr}$ vs. $\mathrm{Zr} / \mathrm{Y}$. Oxides in wt.\%, trace elements in ppm, depth in meters. 
Paranapanema (par) flows. Due to the strong depletion in incompatible elements, the Ribeira (rib) data are in perfect agreement to those reported by Machado et al. (2015) for this type of magma.

Urubici (uru) flows have a multi-element distribution pattern different from the other ones. Despite the small number (2) of samples, it is interesting to note that they are also different from the Urubici basalts that occur in southern PCFB province, where the incompatible element ratios are always higher than Pitanga type (Peate et al. 1999). This distinction could mean that the Urubici from the northern Paraná Continental Flood Basalt has a different origin and/or magmatic evolution when compared to southern Paraná, even though presenting similar contents of $\mathrm{TiO}_{2}, \mathrm{P}_{2} \mathrm{O}_{5}$ and $\mathrm{Sr}$, and $\mathrm{Ti} / \mathrm{Y}$ ratios. Some of these geochemical differences can be associated with the mineralogy of such rocks, including the presence of primary sulfide (pyrite, arsenopyrite) up to $1 \%$, also verified in the surface samples in Machado et al.

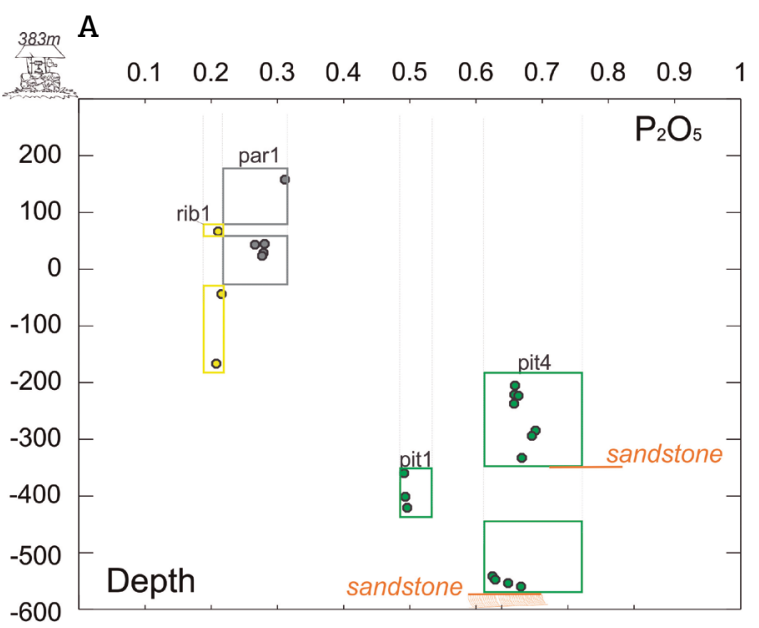

C

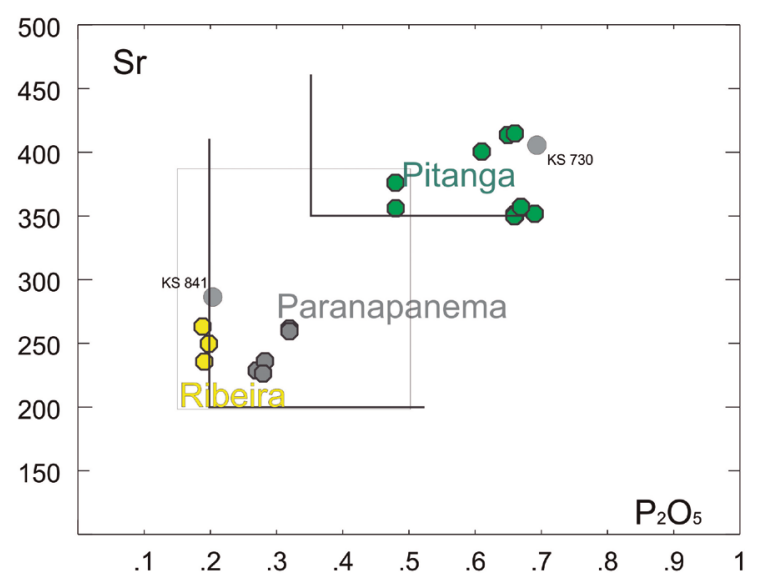

(2007). Although the LILE enrichment of these rocks could be the result of crustal material involvement (Faure 2001), the $\mathrm{Rb} / \mathrm{Ba}$ ratio (0.5-0.9), normalized to the primitive mantle, does not corroborate this possibility.

The data also show that, among the identified Pitanga and Paranapanema magma types, pit 5 is the most enriched in $\mathrm{P}_{2} \mathrm{O}_{5}$, followed by pit4, pit1, pit2, pit3 and par1. It is important to emphasize that the thickest boreholes tend to present the largest diversity in $\mathrm{P}_{2} \mathrm{O}_{5}$, leading to the conclusion of possible multiple effusion points. Low-pressure magmatic differentiation processes may also have contributed to generating additional geochemical variability of the observed flows.

The maximum thicknesses calculated for the different flow sequences are:

pit1: $200 \mathrm{~m}$;

pit2: $100 \mathrm{~m}$;

pit3: $350 \mathrm{~m}$;

pit4: $150 \mathrm{~m}$;

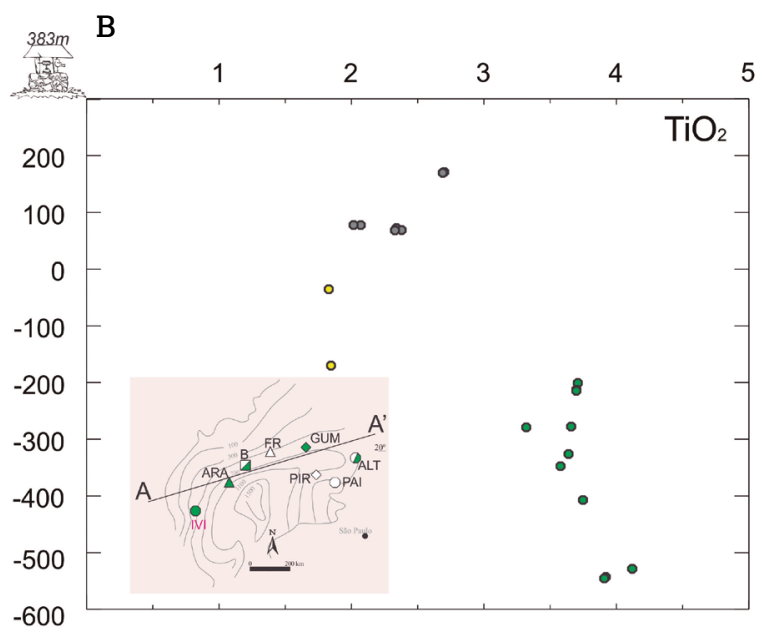

D

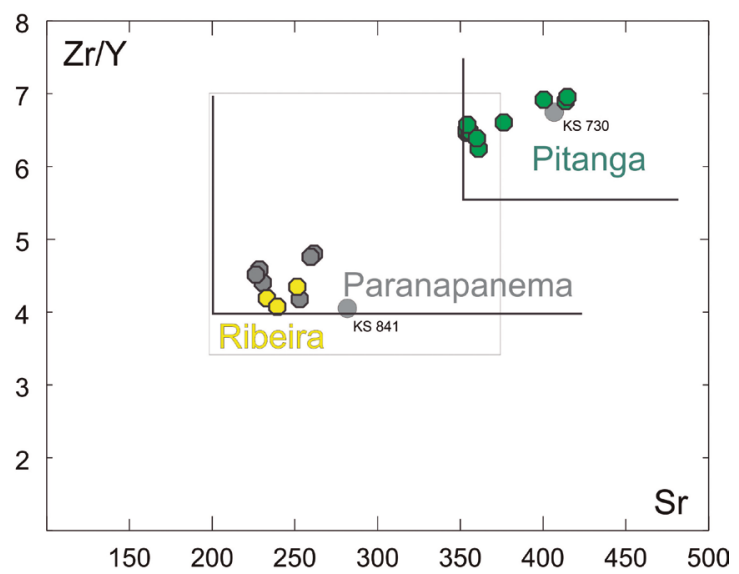

Figure 16. Selected variation diagrams illustrating distinctions between flow sequences in IVI borehole and samples surface: (A) Depth vs. $\mathrm{P}_{2} \mathrm{O}_{5}$; (B) Depth vs. $\mathrm{TiO}_{2}$; (C) $\mathrm{P}_{2} \mathrm{O}_{5}$ vs. Sr; (D) Sr vs. Zr/Y. Oxides in wt.\%, trace elements in $\mathrm{ppm}$, depth in meters. 
pit5: $50 \mathrm{~m}$;

par1:250m;

par2: $170 \mathrm{~m}$;

uru1: $30 \mathrm{~m}$;

rib1: $150 \mathrm{~m}$.

The total pile of Pitanga magma type has a maximum thickness of $850 \mathrm{~m}$, while the Paranapanema, Ribeira and Urubici have, 420, 150 and $30 \mathrm{~m}$, respectively. The thicknesses increase towards the depocenter of the Paraná Basin (Fig. 17).

The Paranapanema magma occurs at the upper part of the central portion of the Paraná Basin in the B, ARA and IVI boreholes. The last one also presents interbedded Ribeira type (Fig. 17). The B and ARA boreholes have a similarity in the sequence of flows that suggest an erosion of at least $170 \mathrm{~m}$ of Paranapema type in the region nearby the B borehole.

Still concerning the Paranapanema magma type, the par1 flows occur between $-400 \mathrm{~m}$ to $-200 \mathrm{~m}$, with a similar a thickness in the ARA, B, and FR boreholes, whereas Par2 flows are only found at the bottom of the FR borehole.
It is remarkable that at the bottom of IVI, ARA and B boreholes there is a conspicuous presence of pit 4 and pit1 flows for a distance as long as $387 \mathrm{~km}$. Moreover, the B borehole has a sequence of par 1 and pit 1 that repeats in the FR borehole at the same level. This shows a good correlation between the ARA, B and FR boreholes in a distance of 147 $\mathrm{km}$. Individual basaltic flows extending for more than 100 $\mathrm{km}$ (in length) in flat areas, such as those of Columbia River, are reported in the literature (Self et al. 1997). For the investigated area, the data indicate that, between the ARA and $\mathrm{B}$ boreholes, the flows run for at least $27 \mathrm{~km}$, if single eruption sites are admitted for effusive points to the observed sequences.

The sequence of flows in the GUM borehole (pit1, pit4, and pit3), excluding the Urubici magma type, is repeated in the intermediate portion of the FR borehole between level 50 to $-100 \mathrm{~m}$ for a distance of approximately $300 \mathrm{~km}$.

Pit1 flows occur at the top of the ALT, PAI, PIR and FR boreholes, but have no equivalent in the lower sequences. On the other hand, pit5 is restricted to the ALT borehole, representing the basalts with the highest $\mathrm{MgO}$ investigated in the present study (Fig. 5).

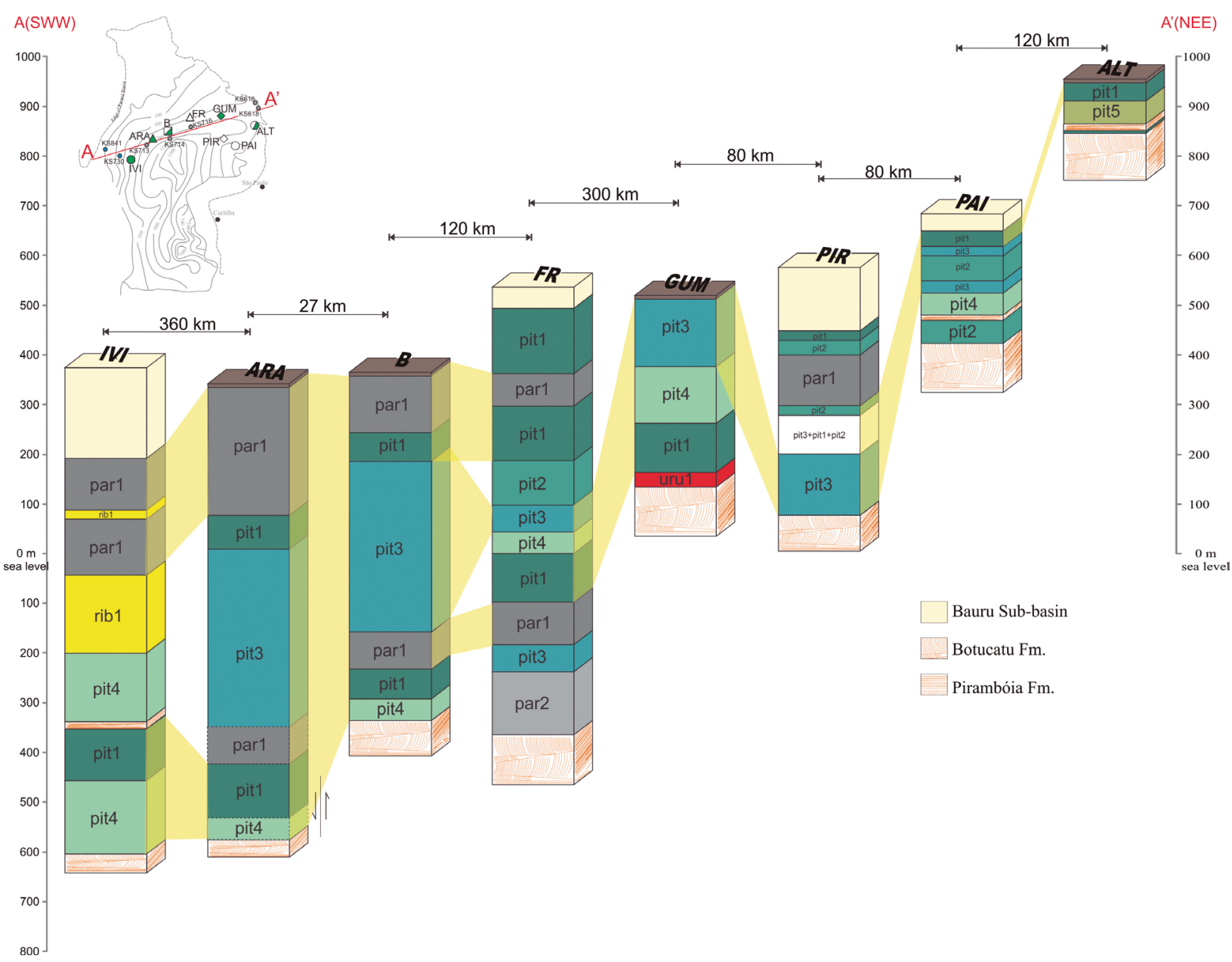

Figure 17. Compilation of identified flow sequences from the 10 studied boreholes. The data show good correlations between FR, B, ARA and IVI boreholes. Colors are the same used in Tab. 2. 
The Paranapanema (par1) flows would necessarily require multiple sources, possibly in the region around ARA, IVI and B boreholes, to reach distances greater than $100 \mathrm{~km}$ with decreasing thickening towards the east (FR borehole). The same happens with the pit 3 flows, with great thickening in the ARA and B borehole and thinning towards GUM, located $400 \mathrm{~km}$ far.

Finally, considering only the magma types, it was possible to elaborate a schematic stratigraphic geochemical column. Fig. 18 shows a schematic chemostratigraphic column for the northern part of the Paraná Continental Flood Basalt province, considering only the magma types. Urubici and par2 are omitted in view of their restricted occurrence in the area. Pitanga are the most voluminous, reaching maximum thicknesses of $750 \mathrm{~m}$, and are succeeded by up to $250 \mathrm{~m}$ of Paranapanema. Ribeira has much lower thicknesses $(<30 \mathrm{~m})$ and is found at the basis of the sequence, directly over the Botucatu Formation (Machado et al. 2014) and, in the case of borehole IVI, intercalated with par1, above some Pitanga flows.

\section{ACKNOWLEDGMENTS}

The authors would like to thank Conselho Nacional de Desenvolvimento Científico e Tecnológico - CNPq (Process no. 482911/2011-5) and Fundação de Amparo à Pesquisa do Estado de São Paulo (Fapesp) (Process no. 2012/06082-6) for financial support. Thanks are due to Sergio Valente, Valdecir de Assis Janasi and an anonymous reviewer for fruitful contributions that considerably improved the manuscript. AJRN and LSM are CNPq Fellow Researchers.

\section{SUPPLEMENTARY DATA}

Supplementary data associated with this article can be found in the online version: Suplementary Table A1.

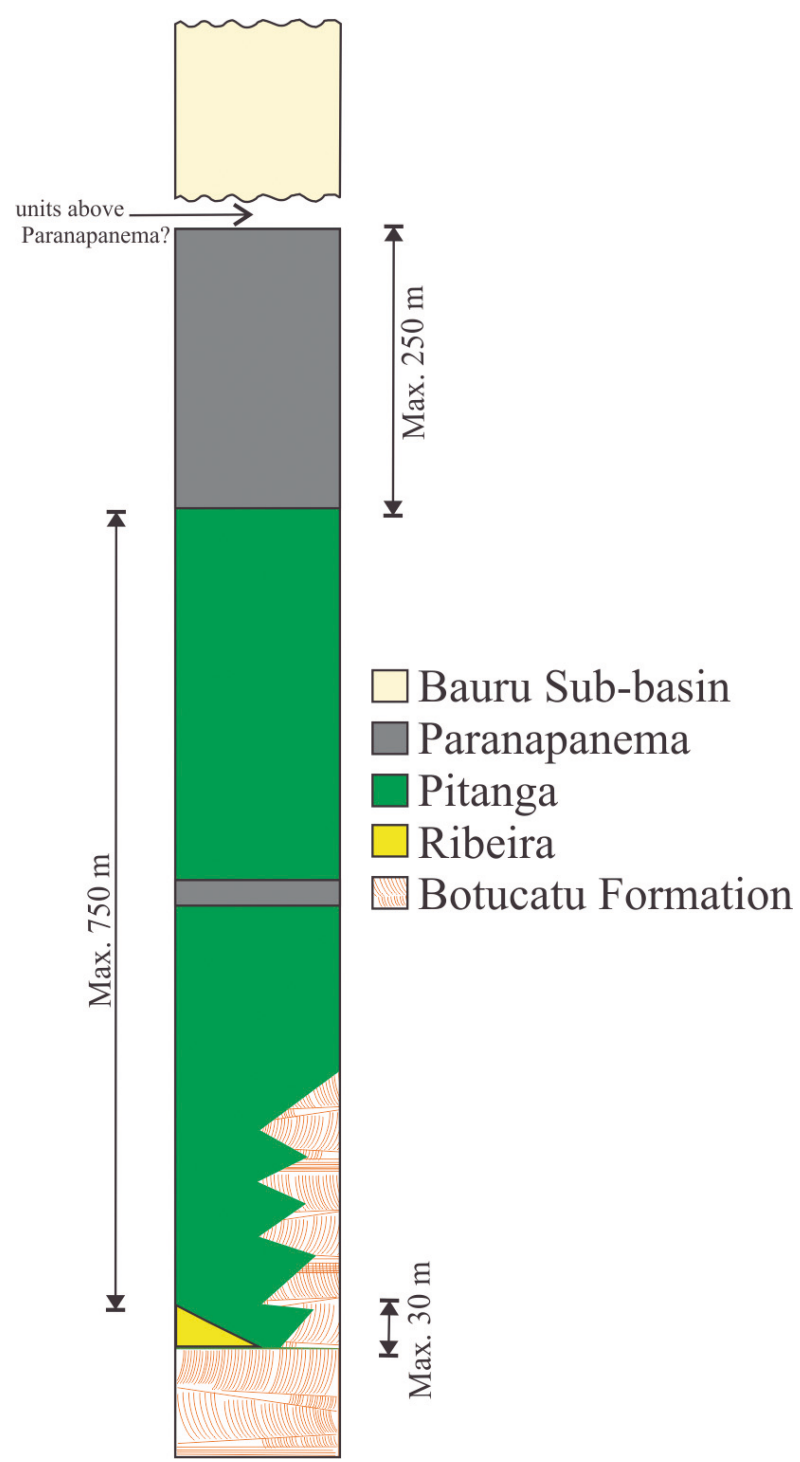

Figure 18. General geochemical stratigraphy column in the north of PCFB.

\section{REFERENCES}

Almeida F.F.M., Assine M.L., Carneiro C.D.R. 2012.A Megadesertificação Mesozóica. In: Hasui Y., Carneiro C.D.R., Almeida F.F.M., Bartorelli A. (Eds.). Geologia do Brasil. São Paulo, Beca, p. 419-428.

Anderson D.L. 2002. Occam's Razor: Simplicity, Complexity, and Global Geodynamics. Proceedings of the American Philosophical Society, 146:56-76.

Assine M.L., Soares P.C. 1995. Interação flúvio-eólica na Formação Pirambóia. In: Simpósio Geologia do Nordeste, 4, Águas de São Pedro. Anais... Águas de São Pedro, Sociedade Brasileira de Geologia, p. 65.

Avini Y., Segev A., Ginat H. 2012. Oligocene regional denudation of the northern Afar dome: pré-and syn-breakup stages of the AfroArabian plate. Geological Society of America Bulletin, 124:18711897. https://doi.org/10.1130/B30634.1
Basilici G., Sgarbi G.N., Führ Dal' Bó. 2012. A sub-bacia Bauru: um sistema continental entre deserto e cerrado. In: Hasui Y., Carneiro C.D.R., Almeida F.F.M., Bartorelli A. (Eds.). Geologia do Brasil. São Paulo, Beca, p. 520-543.

Beane J.E., Turner C.A., Hooper P.R., Subbarao K.V., Walsh J.N. 1986. Stratigraphy, composition and form of the Deccan basalts, Western Ghats, India. Bulletin of Volcanology, 48:61-83. https://doi. org/10.1007/BF01073513

Bellieni G., Brotzu P., Comin-Chiaramonti P., Ernesto M., Melfi A.J., Pacca I.G., Piccirilo E.M., Stolva D. 1983. Petrological and Paleomagnetic Data on the Plateau Basalts to Rhyolite sequences of the Southern Paraná Basin (Brazil). Anais da Academia Brasileira de Ciências, 55:355-383. 
Bellieni G., Comin-Chiaramonti P., Marques L.S., Melfi A.J., Nardy A.J.R., Papatrechas C., Piccirillo E.M., Roisenberg A. 1986. Petrogenetic aspects of acid and basaltic lavas from the Paraná plateau (Brazil): geological, mineralogical and petrochemical relationships. Journal of Petrology, 27:915-944. https://doi.org/10.1093/petrology/27.4.915

Bellieni G., Comin-Chiaramonti P., Marques L.S., Melfi A.J., Piccirilo E.M., Nardy A.J.R., Roisenberg A. 1984. High-and low-Ti flood basalts from the Paraná plateou (Brazil): petrology and geochemical aspects bearing on their mantle origin. Neues Jahrbuch für Mineralogie Abhandlungen, 150:272-306.

Bertrand H., Fornari M., Marzoli A., García-Duarte R., Sempere T. 2014. The Central Atlantic Magmatic Province extends into Bolivia. Lithos, 188:33-43. https://doi.org/10.1016/j.lithos.2013.10.019

Bryan S., Ernst R.E. 2008. Revised definition of Large Igneous Provinces (LIPs). Earth-Science Reviews, 86:175-202. https://doi. org/10.1016/j.earscirev.2007.08.008

Camp V.E., Hanan B.B. 2008. A plume-triggered delamination origin for the Columbia River Basalt Group. Geosphere, 4:480-495. https:// doi.org/10.1130/GES00175.1

Chenet A.L., Fluteau F., Courtillot V., Gérard M., Subbarao K.V. 2008. Determination of rapid Deccan eruptions across the CretaceousTertiary boundary using paleomagnetic secular variation: result from a 1200-m-thick section in the Mahabaleshwar escarpment. Journal of Geophysical Research, 113:101. https://doi. org/10.1029/2006JB004635

Coffin M.F., Eldholm O. 1991. Large Igneous Province: JOI/USSAC workshop report, Tech. Rep. 114. Austin, Institute for Geophysics, University of Texas. $79 \mathrm{p}$.

Coffin M.F., Eldholm O. 1992. Volcanism and continental breakup: a global compilation of large igneous provinces. In: Storey B.C., Alabaster T., Pankhurst R.J. (Eds.). Magmatism and Causes of Continental Break-up, Geological Society, Special Publication, 68:17-30.

Coffin M.F., Eldholm O. 1993a. Large igneous provinces. Scientific American, 269:42-49.

Coffin M.F., Eldholm O. 1993b. Scratching the surface: estimating dimensions of large igneous province. Geology, 21:515-518. https:// doi.org/10.1130/0091-7613(1993)021\%3C0515:STSEDO\%3E2.3.CO;2

Coffin M.F., Eldholm O. 1994. Large igneous provinces: crustal structure, dimensions, and external consequences. Review of Geophysics, 32:1-36. https://doi.org/10.1029/93RG02508

Coffin M.F., Eldholm O. 2005. Large igneous provinces. In: Selley R.C., Cocks R., Plimer I.R. (Eds.). Encyclopedia of Geology. Oxford, Elsevier, p. 315-323.

Courtillot V., Renne P.R. 2003. On the ages of flood basalt events. Comptes Rendus Géoscience, 335:113-140. https://doi.org/10.1016/ S1631-0713(03)00006-3

Cox K.G., Hawkesworth C.J. 1985. Geochemical stratigraphy of the Deccan Traps at Mahabaleshwar, Western Ghats, India, with implications for open system magmatic processes. Journal of Petrology, 26(2):355-377. https://doi.org/10.1093/petrology/26.2.355

Ernesto M., Raposo M.I.B., Marques L.S., Renne P.R., Diogo L.A., De Min A. 1999. Paleomagnetism, geochemistry and ${ }^{40} \mathrm{Ar} /{ }^{39} \mathrm{Ar}$ dating of the North-eastern Paraná magmatic province: tectonic implications. Journal of Geodynamics, 28:321-340. https://doi.org/10.1016/ S0264-3707(99)00013-7

Ernst R.E. 2014. Large Igneous Provinces. Cambridge, Cambridge University Press, 653 p.

Ernst R.E., Buchan K.L. 2001. Mantle Plumes: Their identification through time. Geological Society of America, 352. https://doi.org/10.1130/SPE352
Ernst R.E., Buchan K.L. 2003. Recognizing mantle plumes in the geological record. Annual Review Earth and Planetary Science, 31:469523. https://doi.org/10.1146/annurev.earth.31.100901.145500

Ewart A., Marsh J.S., Milner S.C., Duncan A.R., Kamber B.S., Armstrong A.R. 2004. Petrology and geochemistry of Early Cretaceous bimodal continental floodvolcanism of the NW Etendeka, Namibia. Part 1. Introduction, mafic lavas and reevaluation of mantle source components. Journal of Petrology, 45:59-105. https://doi. org/10.1093/petrology/egg083

Faure G. 2001. Origin of Igneous Rocks: The Isotopic Evidence. New York, Springer, $494 \mathrm{p}$

Franco-Magalhães A.O.B., Cuglieri M.A.A., Hackspacher P.C., Saad A.R. 2013. Long-term landscape evolution and post-rift reactivation in the southeastern Brazilian passive continental margin: Taubate basin. International Journal of Earth Sciences, 103:441-453.

Glen J.M.G., Ponce D.A. 2002. Large-scale fractures related to inception of Yellowstone hot spot. Geology, 30:647-650.

Gudmundsson A., Pasquarè F.A., Tibaldi A. 2014. Dykes, Sills, Laccoliths, and Inclined Sheets in Iceland. In: Nemeth K. (Ed.) Advances in Volcanology. New York, Springer, 17 p.

Hawkesworth C.J., Gallagher K., Kelley S., Mantovani M., Peate D.W., Regelous M., Rogers N.W. 1992. Paraná magmatism and the opening of the South Atlantic. In: Storey B.C., Alabaster T., Pankhurst R.J. (Eds.). Magmatism and the Causes of Continental Break-up, Special Publication of Geology Society London, 68:221-240

Hooper, P.R. 1997. Chemical discrimination of Columbia River basalt flows. Geochemistry, Geophysics, Geosystems, 1:1-14. https://doi. org/10.1029/2000GC000040

Ivanov A.V., He H.Y., Yan L.-K., Ryabov V.V., Shevko A.Y., Palesskii S.V., Nikolaeva I.V. 2013. Siberian Traps large igneous province: evidence for two flood basalt pulses around the Permo-Triassic boundary and in the Middle Triassic, and contemporaneous granitic magmatism. Earth Science Reviews, 122:58-76. https://doi.org/10.1016/j.earscirev.2013.04.001

Janasi V.A., Freitas V.A., Heaman L.H. 2011. The onset of flood basalt volcanism, Northern Paraná Basin, Brazil: A precise U$\mathrm{Pb}$ baddeleyite/zircon age for a Chapecó-type dacite. Earth and Planetary Science Letters, 302:147-153. https://doi.org/10.1016/j. epsl.2010.12.005

Jerram D.A., Widdowson M. 2005. The anatomy of Continental Flood Basalt Provinces: geological constraints on the processes and products of flood volcanism, Lithos, 79(3-4):385-405. https://doi. org/10.1016/j.lithos.2004.09.009

Kirstein L.A., Peate D.W., Hawkesworth C.J., Turner S.P., Harris C Mantovani M.S.M. 2000. Early Cretaceous basaltic and rhyolitic magmatism in southern Uruguay associated with the opening of the South Atlantic. Journal of Petrology, 41:1413-1438. https://doi. org/10.1093/petrology/41.9.1413

Le Maitre R.W. 2002. Igneous rocks a Classification and Glossary of Terms Recommendations of the International Union of Geological Sciences, Sub-Commission on the Systematics of Igneous Rocks. Cambridge, Cambridge University Press, 236 p.

Lustrino M., Marrazzo M., Melluso L., Tassinari C.G.C., Brotzu P. Gomes C.B., Morbidelli L., Ruberti E. 2010. Petrogenesis of Early Cretaceous silicic volcanismin SE Uruguay: the role of mantle and crustal sources. Geochemical Journal, 44:1-22. https://doi. org/10.2343/geochemj.1.0042

Lustrino M., Melluso L., Brotzu P., Gomes C.B., Morbidelli L., Muzio R., Ruberti E., Tassinari C.G.C. 2005. Petrogenesis of the early Cretaceous Valle Chico igneouscomplex (SE Uruguay): relationship with ParanáEtendeka magmatism. Lithos, 82:407-434. https://doi.org/10.1016/j. lithos.2004.07.004 
MacDonald G.A., Katsura I. 1964. Chemical Composition of Hawaiian Lavas. Journal of Petrology, 5:82-133. https://doi.org/10.1093/ petrology/5.1.82

MacDougall J.D. 1988. Continental Flood Basalts. Dordrecht, Kluwer Academic Publishers, $341 \mathrm{p}$.

Machado F.B. 2010. Petrologia e Caracterização das Fontes Mantélicas dos derrames de lava da região noroeste da Província Magmática do Paraná. Thesis, Universidade Estadual Paulista "Júlio de Mesquita Filho", Rio Claro, 260 p.

Machado F.B., Nardy A.J.R., Oliveira M.A.F. 2007. Geologia e aspectos petrológicos das rochas intrusivas e efusivas mesozóicas de parte da borda leste da Bacia do Paraná no Estado de São Paulo. Revista Brasileira de Geociências, 37:64-80.

Machado F.B., Nardy A.J.R., Rocha-Júnior E.V.R., Marques L.S., Oliveira M.A.F. 2009. Geologia e litogeoquímica da Formação Serra Geral nos Estados de Mato Grosso e Mato Grosso do Sul. Geociências, 28:523-540.

Machado F.B., Rocha-Júnior E.V., Nardy A.J.R., Marques L.S. 2014. Low titanium magmatism in northwest region of Paraná continental flood basalts (Brazil): volcanological aspects. Solid Earth Discussions, 6:2215-2259. http://dx.doi.org/10.5194/sed-6-2215-2014

Machado F.B., Rocha-Júnior E.V.R., Marques L.S., Nardy A.J.R. 2015. Volcanological aspects of the northwest region of Paraná continental flood basalts (Brazil). Solid Earth, 6:227-241. https://doi.org/10.5194/ se-6-227-2015

Mahoney J.J., Sheth H.C., Chandrasekharam D., Peng Z.X. 2000. Geochemistry of flood basalts of the Toranmal section, northern Deccan Traps, India: implications for regional Deccan stratigraphy. Journal of Petrology, 41:1099-1120. https://doi.org/10.1093/petrology/41.7.1099

Mantovani M.S.M., Marques L.S., Souza M.A., Civeta L., Atalla L., Inonocenti F. 1985. Trace Element and Strontium Isotope Constrains of the Origin and Evolution of Paraná Continental Flood Basalts of Santa Catarina State (Southern Brazil). Journal of Petrology, 26:187209. https://doi.org/10.1093/petrology/26.1.187

Mantovani M.S.M., Peate D.W., Hawkesworth C.J. 1988. Geochemical stratigraphy of the Paraná continental flood basalts: a contribution from boreholes. In: Piccirillo E.M., Melf A.J. (Eds.). Mesozoic flood volcanism from the Paraná Basin (Brazil): petrogenetic and geophysical aspects. São Paulo, Instituto Astronômico e Geofísico Publishers, p. 15-24.

Marques L.S., De Min A., Rocha-Júnior E.R.V., Babinski M., Bellieni G., Figueiredo A.M.G. 2017. Elemental and Sr-Nd-Pb isotope geochemistry of the Florianópolis Dyke Swarm (Paraná Magmatic Province): Crustal contamination and mantle source constraints. Journal of Volcanology and Geothermal Research. https://doi.org/10.1016/j.jvolgeores.2017.07.005

Marques L.S., DupréB., Piccirillo E.M. 1999. Mantlesource compositions of the Paraná Magmatic Province: evidence from trace element and $\mathrm{Sr}$ - Nd - Pb isotope geochemistry. Journal of Geodynamics, 28:439458. https://doi.org/10.1016/S0264-3707(99)00020-4

Marques L.S., Piccirillo E.M., Melf A.J., Comin-Chiaramonti P., Bellieni G. 1989. Distribuição de terras raras e outros elementos traços em basaltos da Bacia do Paraná. Geochimica Brasiliensis, 3:33-50. http:// dx.doi.org/10.21715/gb.v1i3.23

Marques L.S., Rocha-Júnior E.R.V., Babinski M., Carvas K.Z., Petronilho L.A., De Min A. 2016. Lead isotope constraints on the mantle sources involved in the genesis of Mesozoic high-Ti tholeiite dykes (Urubici type) from the São Francisco Craton (Southern Espinhaço, Brazil). Brazilian Journal of Geology, 46(Suppl. 1):105-122. http://dx.doi. org/10.1590/2317-4889201620150010

Marsh J.S., Ewart A., Milner S.C., Duncan A.R., Miller R. McG. 2001. The Etendeka igneous province: magma types and their stratigraphic distribution with implications for the evolution of the ParanáEtendeka flood basalt province. Bullettin of Volcanology, 62:464-486. https://doi.org/10.1007/s004450000115
McDonough W.F., Sun S. 1995. The composition of the Earth. Chemical Geology, 120:223-253. https://doi.org/10.1016/0009-2541(94)00140-4

Miyashiro A. 1978. Nature of Alkalic Volcanic Rock Series. Contributions to Mineralogy and Petrology, 66:91-104. https://doi. org/10.1007/BF00376089

Nardy A.J.R., Enzweiler J., Bahia Filho O., Oliveira M.A.F. de, Penereiro M.A.V. 1997. Determinação de Elementos Maiores e Menores em Rochas Silicáticas por Espectrometria de Fluorescência de Raios-X: Resultados Preliminares. In: Congresso Brasileiro de Geoquímica, 6. Salvador. Actas... v. 1. p. 346-348

Nardy A.J.R., Machado F.B., Oliveira M.A.F. 2008. As rochas vulcânicas mesozóicas ácidas da Bacia do Paraná: litoestratigrafia e considerações geoquímico-estratigráficas. Revista Brasileira de Geociências, 38:178-195.

Nardy A.J.R., Oliveira M.A.F.; Betancourt R.H.S., Verdugo D.R.H., Machado F.B. 2002. Geologia e estratigrafia da Formação Serra Geral. Revista de Geociências, 21:15-32.

Navarro M.S., Andrade S., Ulbrich H., Gomes C.B., Girardi V.A.V. 2008. The Direct Determination of Rare Earth Elements in Basaltic and Related Rocks using ICP-MS: Testing the Efficiency of Microwave Oven Sample Decomposition Procedures. Geostandards and Geoanalytical Research, 32(2):167-180. https://doi. org/10.1111/j.1751-908X.2008.00840.x

Peate D.W., Hawkesworth C.J. 1996. Lithospheric to asthenospheric transition in Low-Tiflood basalts from southern Parana, Brazil. Chemical Geology, 127:1-24. https://doi.org/10.1016/0009-2541(95)00086-0

Peate D.W., Hawkesworth C.J., Mantovani M.S.M. 1992. Chemical stratigraphy of the Paraná lavas (S. America): classification of magma types and their spatial distribution. Bulletin of Volcanology, 55:119-139. https://doi.org/10.1007/BF00301125

Peate D.W., Hawkesworth C.J., Mantovani M.S.M., Rogers N.W., Turner S.P. 1999. Petrogenesis and stratigraphy of the high-Ti/Y Urubici magma type in the Paraná flood basalt province and implications for the nature of Dupal-type mantle in the South Atlantic region. Journal of Petrology, 40:451-473. https://doi. org/10.1093/petroj/40.3.451

Peate D.W., Mantovani M.S.M., Hawkesworth C.J. 1988. Geochemical stratigraphy of the Paraná continental flood basalts: borehole evidence. Revista Brasileira de Geociencias, 18:212-221.

Piccirillo E.M., Comin-Chiaramonti P., Melfi A.J., Stolfa D., Bellieni G., Marques L.S., Giaretta A., Nardy A.J.R., Pinese J.P.P., Raposo M.I.B., Roisenberg A. 1988. Petrichemistry of Continental Flood Basalt-Rhyolite Suites and Related Intrusives from the Paraná Basin (Brazil). In: Piccirilo E.M., Melf A.J. (Eds.). The Mesozoic Flood Volcanism of the Paraná Basin: Petrogenetic and Geophysical Aspects. São Paulo, Instituto Astronômico e Geofísico, Universidade de São Paulo, p. 107-156.

Piccirillo E.M., Melfi A.J. 1988. The Mesozoic flood volcanism of the Paraná Basin: petrogenetic and geophysical aspects. São Paulo, Instituto Astronômico e Geofísico, Universidade de São Paulo, $600 \mathrm{p}$.

Quintas M.C.L., Mantovani M.S.M., Zalán P.V. 1999. Contribuição ao estudo da evolução mecânica da Bacia do Paraná. Revista Brasileira de Geociências, 29(2):217-226.

Renne P.R., Deckart K., Ernesto M., Féraud G., Piccirillo E.M. 1996. Age of the Ponta Grossa dike swarm (Brazil), and implications to Paraná flood volcanism. Earth and Planetary Science Letters, 144:199-211. https:/doi.org/10.1016/0012-821X(96)00155-0

Renne P.R., Ernesto M., Pacca I.G., Coe R.S., Glen J.M., Prévot M., Perrin M. 1992. The Age of Paraná Flood Volcanism, Rifting of Gondwanaland, and the Jurassic-Cretaceous Boundary. Science, 258:975-979. https://doi.org/10.1126/science.258.5084.975 
Riedel S.P., Camp V.E., Tolan T.L., Martin B.S. 2013. The Columbia River flood basalt province: stratigraphy, areal extend, volume, and physical volcanology. In: Reidel S.P., Camp V.E., Ross M.E., Wolff J.A., Martin B.S., Tolan T.L., Wells R.E. (Eds.). The Columbia River Flood Basalt Province. Geological Society of America Special Paper, 497:1-43

Rocha-Júnior E.R.V., Marques L.S., Babinski M., Nardy A.J.R., Figueiredo A.M.G., Machado F.B. 2013. Sr-Nd-Pb isotopic constraints on the nature of the mantle sources involved in the genesis of the high-Ti tholeiites from northern Paraná Continental Flood Basalts (Brazil). Journal of the South American Earth Science, 46:9-25. http:// dx.doi.org/10.1016/j.jsames.2013.04.004

Rocha-Júnior E.R.V., Puchtel I.S., Marques L.S., Walker R.J., Machado F.B., Nardy A.J.R., Babinski M., Figueiredo A.M.G. 2012. Re-Os isotope and highly siderophile element systematics of the Paraná continental flood basalts (Brazil). Earth and Planetary Science Letters, 337:164-173.

SchererC.M.S. 2000. Eolian dunes of the Botucatu Formation (Cretaceous) in Southernmost Brazil: morphology and origin. Sedimentary Geology, 137:63-84. https://doi.org/10.1016/S0037-0738(00)00135-4

Self S., Thordarson T., Keszthelyi L. 1997. Emplacement of continental flood basalts flows. In: Mahoney J.J., Coffin M. (Eds.). Large Igneous Provinces. American Geophysical Union, 100:381-410.

Sheth H.C. 2007. 'Large Igneous Provinces (LIPs)': Definition, recommended terminology, and a hierarchical classification. Earth-Science Reviews, 85(3):117-124. https://doi.org/10.1016/j.earscirev.2007.07.005
Stewart K., Turner S., Kelley S., Hawkesworth C., Kirstein L., Mantovani M. 1996. 3D, ${ }^{40} \mathrm{Ar}-{ }^{39} \mathrm{Ar}$ geochronology in the Paraná continental flood basalt province. Earth and Planetary Science Letters, 143:95109. https://doi.org/10.1016/0012-821X(96)00132-X

Subbarao K.V., Bodas M.S., Hooper P.R., Walsh J.N. 1988. Petrogenesis of Jawhar and Igatpuri Formations, Western Deccan Basalt Province, India. In: Subbarao K.V. (Ed.). Deccan Flood Basalts. India, Geology Society of India, 10:253-280

Thiede D.S., Vasconcelos P.M. 2010. Paraná flood basalts: rapid extrusion hypothesis confirmed by new 40Ar/39Ar results. Geology, 38:747-750. https://doi.org/10.1130/G30919.1

Torres M.,OliveiraM.A.F.,NardyA.J.R.,MachadoF.B.2008.Litogeoquímica e Quimioestratigrafia dos Basaltos da Província Magmática do Paraná, no Município de Araçatuba. Revista Brasileira de Geociências, 38:544553. https://doi.org/10.25249/0375-7536.2008383544553

Turner S., Regelous M., Kelley S., Hawkesworth C.J., Mantovani M.S.M. 1994. Magmatism and continental break-up in the South Atlantic: high precision ${ }^{40} \mathrm{Ar}-{ }^{39} \mathrm{Ar}$ geochronology. Earth and Planetary Science Letters, 121:333-348. https://doi.org/10.1016/0012-821X(94)90076-0

Zalán P.V., Wolf S., Conceição J.C.J., Astolf M.A.M., Vieira I.S., Appi V.T., Zanotto O.A. 1987. Tectônica e sedimentação da Bacia do Paraná. In: Simpósio Sul-Brasileiro de Geologia, 3., Curitiba. Actas... Curitiba, Sociedade Brasileira de Geologia, v. 1, p. 441-473. 